\title{
Atmosferik Plazma Teknolojisi Kullanılarak Cep Telefonu Koruma Malzemelerine Antimikrobiyal Özellik Kazandırılması
}

\author{
Ece İrem Çoban ${ }^{1}$, Gülşah Arslan², Fikret Keven Karademir ${ }^{3}$, Fatma Ayhan ${ }^{4}$, Hakan Ayhan ${ }^{5 *}$ \\ ${ }^{1}$ İTÜ ETA Vakfı Doğa Koleji, Zonguldak Ereğli Kampüsü, Zonguldak, Türkiye. (ORCID: 0000-0002-8745-5184), eceiremcoban@hotmail.com \\ ${ }^{2}$ Muğla Sıtkı Koçman Üniversitesi, Fen Fakültesi, Kimya Bölümü, Biyokimya Anabilimdalı, Biyokimya\& Biyomalzemeler Araştırma Grubu (BIOMATREG), Muğla, \\ Türkiye. (ORCID: 0000-0002-4362-2112), gulsah.arslan@outlook.com \\ ${ }^{3}$ Muğla Sıtkı Koçman Üniversitesi, Sağlık Hizmetleri Meslek Yüksekokulu, Marmaris, Muğla, Türkiye. (ORCID: 0000-0003-0523-8221), fkarademir@mu.edu.tr \\ ${ }^{4}$ Muğla Sitkı Koçman Üniversitesi, Fen Fakültesi, Kimya Bölümü, Biyokimya Anabilimdalı, Biyokimya\& Biyomalzemeler Araştırma Grubu (BIOMATREG), Muğla, \\ Türkiye (ORCID: 0000-0003-2220-4496), fayhan@mu.edu.tr \\ ${ }^{5}$ Muğla Sitkı Koçman Üniversitesi, Fen Fakültesi, Kimya Bölümü, Biyokimya Anabilimdalı, Biyokimya\& Biyomalzemeler Araştırma Grubu (BIOMATREG), Muğla, \\ Türkiye (ORCID: 0000-0003-2911-1655), hayhan48@ gmail.com
}

(İlk Geliş Tarihi 1 Ekim 2020 ve Kabul Tarihi 16 Aralık 2020)

(DOI: 10.31590/ejosat.798436)

ATIF/REFERENCE: Çoban, E. İ., Arslan, G., Karademir, F. K., Ayhan, F. \& Ayhan, H. (2021). Atmosferik Plazma Teknolojisi Kullanılarak Cep Telefonu Koruma Malzemelerine Antimikrobiyal Özellik Kazandırılması. Avrupa Bilim ve Teknoloji Dergisi, (21), 53-66.

\section{$\ddot{O} \mathbf{z}$}

Sağlık çalışanları arasında zayıf el hijyeni uyumluluğu ve dezenfekte edilmiş yüzeylerin elle temas yoluyla yeniden kontaminasyonu, antimikrobiyal yüzey kaplamalarına olan gereksinimi ortaya koymuştur. Sağlık çalışanlarının telefonlarının yüzeylerinde ise nozokomiyal enfeksiyonlara neden olan mikroorganizmaların bulunduğu belirlenmiştir. $\mathrm{Bu}$ çalışmada sağlık çalışanlarının telefonlarının yüzeylerindeki mikroorganizmaların belirlenmesi ve cep telefonu koruma malzemelerine atmosferik plazma yöntemiyle antimikrobiyal özellik kazandırılması amaçlanmıştır.

Çalsşmanın ilk aşamasında; tam teşekküllübir hastanede çalışan 40 sağlık personelinin telefonlarının yüzeyinden eküvyon ile örnek alınmıştır. Mikrobiyolojik analizler sonucunda; sağlık çalışanlarının \%90'ının telefonlarında çeşitli mikroorganizmaların ürediği belirlenmiştir. Bu mikroorganizmalardan metisiline dirençli Staphylococcus aureus (S.aureus), Escherichia coli (E.coli) ve Streptococcus pyogenes (S.pyogenes) antimikrobiyal telefon koruma malzemesi deneylerinde kullanılmak üzere izole edilmiştir.

İkinci aşamada; 7 telefon koruma ve 2 ekran koruyucu olmak üzere toplam 9 materyal deneylerde kullanılmak üzere belirlenmiştir. Bu materyallerden 4 telefon koruma 3D yazıcı ile Termoplastik Poliüretan (TPU) ve Polilaktik Asit (PLA) filamentden 0,5mm ve 1,0 $\mathrm{mm}$ kalınlığında yaptırılmıştır. Ticari olarak ise Polikarbonat $\left(\mathrm{PC}^{\circledR}\right)$, TPU ${ }^{\circledR}$ ve TPU/silikon ${ }^{\circledR} 3$ telefon koruma temin edilmişsir. Ekran koruyucu olarak temperli cam $\left(\right.$ flexi $\left.{ }^{\circledR}\right)$ ve nanocam $\left(n a n o^{\circledR}\right) 2$ örnek değerlendirilmiștir. Deney ve kontrol gruplarında kullanılmak üzere 9'ar örnek $1 \mathrm{~cm}$ çapında kesilmiş deney örneklerine plazma polimerizasyon işlemi 3 amper 1 dakika uygulanmıştır. Kontrol grubu örneklere hiçbir işlem uygulanmamıştır. Deney ve kontrol grubu örnekleri metisiline dirençli S.aureus, E.coli ve S.pyogenes içeren besi yerlerine yerleştirilerek inkübasyona bırakılmıştır. Örneklerin antimikrobiyal aktiviteleri disk difüzyon yöntemi ile değerlendirilerek karşılaştırılmıştır.

Bu çalışmada 3 amp. 1 dakika uygulanan plazma modifikasyonu sonucunda deney örneklerinde antimikrobiyal özellik olduğu saptanmıştır. Özellikle ticari olarak temini sağlanan TPU/silikon ${ }^{\circledR}$ ve $\mathrm{PC}^{\circledR}$ telefon korumaları kontrol grubuna göre S.pyogenes üzerinde en güçlü antimikrobiyal özellik göstermiştir. Sağlık çalışanları için plazma polimerizasyonu uygulanmış antimikrobiyal telefon koruma malzemesi üretilmesi, kullanılması ve sonuçlarının değerlendirilmesi önerilebilir.

Anahtar Kelimeler: Cep telefon koruma malzemeleri, Atmosferik plazma yöntemi, Antimikrobiyal etki.

\footnotetext{
${ }^{*}$ Sorumlu Yazar: hayhan48@gmail.com
} 


\title{
Adding Antimicrobial Properties to Mobile Phone Protection Materials by Using Atmospheric Plasma Technology
}

\begin{abstract}
Poor hand hygiene cooperation among health-care workers and re-contamination of disinfected surfaces by hand-contact, proves the need for antimicrobial surface coatings. It was stated that microorganisms responsible with nosocomial infections were present on the surfaces of mobile phones of health care workers. The purpose of this study was to detect the microorganisms on the surfaces of mobile phones of health care workers and acquisition of mobile phone coating materials with antimicrobial properties using atmospheric plasma technique.

In the first phase of study; specimens were obtained from surfaces of mobile phones of 40 health care workers' working in a comprehensive hospital with ecuvion sticks during the first phase of the study. It was observed that various microorganisms cultivated in $90 \%$ of mobile phones of health care workers according to the microbiologic analyses. Among these microorganisms meticillin resistant Staphylococcus aureus (S.aureus), Escherichia coli (E.coli) ve Streptococcus pyogenes (S.pyogenes) were isolated in order to be used during antimicrobial mobile phone coating material experiments.

In the second phase; totally 9 materials of which 7 of them mobile phone cases and 2 of them being screen protectors were designated for use in these experiments. Among those materials 4 phone cases were manufactured at $0.5 \mathrm{~mm}$ and $1 \mathrm{~mm}$ thickness from Thermoplastic Polyurethane (TPU) and Polylactic Acid (PLA) filament with 3D printer. Commercially 3 phone cases were manufactured from Polycarbonate $\left(\mathrm{PC}^{\circledR}\right)$, TPU ${ }^{\circledR}$ and TPU/silicone ${ }^{\circledR} .2$ specimens as Tempered glass $\left(\right.$ flexi $\left.^{\circledR}\right)$ and nanoglass $\left(\right.$ nano $\left.{ }^{\circledR}\right)$ were evaluated as screen protectors. Plasma polymerization process was applied at 3 ampers for 1 minute on 9 experimental specimens which were cut at $1 \mathrm{~cm}$ width. No procedures were applied to the control specimens. Experimental and control group specimens were left to incubation in mediums containing meticillin resistant S. aureus, E. coli and S.pyogenes. Antimicrobial activities of specimens were compared using disc diffusion technique.

It was detected that following 3 amper 1 minute plasma modification, experimental specimens acquired antimicrobial properties. Especially, commercially available TPU/silicone ${ }^{\circledR}$ and $\mathrm{PC}^{\circledR}$ phone cases demonstrated higher antimicrobial properties against S.pyogenes compared with control groups. Plasma polymerization applied antimicrobial phone cover material manufacturing, usage and evaluation of the results can be suggested for health care workers.
\end{abstract}

Keywords: Mobile phone covers materials, Atmospheric plasma technique, Antimicrobial effect.

\section{Giriş}

Dünya çapında milyonlarca hasta her yıl sağlık hizmeti ile ilişkili enfeksiyonlardan etkilenmekte ve bu durum ülkelerin ekonomilerinde de yük oluşturmaktadır (Colum, Dunne, ve ark., 2017). Hastane ortamında sağlık çalışanları tarafindan sıklıkla kullanılan akıllı telefonlar nozokomiyal (hastane) enfeksiyonların gelişimine neden olması açısından riskli araçlar haline dönüşmeye başlamıştır (Chang ve ark., 2017). Sağlık çalışanlarının ellerinde ve akıllı telefonlarında çeşitli türlerde bakteriyel kontaminasyon olduğu belirtilmiş, sağlık çalışanlarının akıllı telefon kullanımının nozokomiyal enfeksiyonun bir kaynağı olabileceği ifade edilmiştir (Ulger ve ark., 2009). Akıllı telefonlar ve bakteriyel çapraz kontaminasyon arasındaki ilişkinin17 ülkeden 4876 sağlık çalışanının verileri ile değerlendirildiği çalışmada; sağlık çalışanlarının akıllı telefonlarında nozokomiyal enfeksiyon etkenlerinin sıklığının $\% 10$ ile \%100 arasında değiştiği bulunmuştur (Ulger ve ark., 2015). Tüm dünyada olduğu gibi Türkiye'de de bir sorun olarak karşımıza çıkan nozokomiyalenfeksiyonların oranının \%5-15 arasında değiştiği kabul edilmektedir. Nozokomiyalenfeksiyona bağlı ölümler, gelişmiş ülkelerde ilk 10 ölüm nedeni arasındadır (Sayıştay Raporu, 2007). Nozokomiyalenfeksiyonlar, hastanede kalış süresini, tedavi maliyetini ve işgücü kaybını artırmakta, özellikle bağışıklık sistemi zayıf olan hastalarda ölümlere yol açabilmektedir. Nozokomiyal enfeksiyonlar; hastalar dışında; mikroorganizma ile teması olan sağlık çalışanları, refakatçi ve ziyaretçiler için de yüksek risk oluşturmaktadır (Sayıştay Raporu, 2007).
Dünya genelinde hastanelerde ve toplumda nozokomiyal enfeksiyona neden olan bakterilerin başında Staphylococcus aureus (S.aureus), Escherichiaecoli (E.coli), Klebsiella pneumoniae, Pseuodomonas, Enterobacter, Acinetobacter gelmektedir (Gürler, 2005). Nozokomiyal epidemilere yol açan mikroorganizmalardan epidemilerin yaklaşık yarısına neden olan metisiline dirençli S.aureus olduğu saptanmıştır (Cercenado, 2000).

$\mathrm{Bu}$ bakterilerde her geçen gün artan direnç nedeniyle sorunlar da giderek artmaktadır. Hastalar ve sağlık çalışanları açısından önemli bir sorun olan bu mikroorganizmalarla temas ve bulaştırma riski yüksek olmasına karşın koruyucu uygulamaların yetersiz kaldığı bilinmektedir (Gürler, 2005). Sağlık çalışanlarının cep telefonlarını; tuvalette kullanması, klinik ortamda kullanımlarını kısıtlamaması (Zakai ve ark., 2016), sürekli hastalarla temas halinde olması ve nadiren cep telefonlarını temizlemek için dezenfektan kullanmaları (Zakai ve ark. 2016; Ulger ve ark. 2015) enfeksiyon riskini arttırmaktadır. Akıllı telefonların bakteri yükünün fazla olmasının yanı sıra sağlık personelinin el hijyeni uyum oranlarının düşük olması da nozokomiyal enfeksiyonların gelişimine neden olmaktadır (Nargiz Koşucu ve ark., 2015). Tüm dünyada olduğu gibi ülkemizde de önemli bir sorun olan nozokomiyal enfeksiyonlar, sağlık çalışanlarının telefonlarında bulunan ilaca dirençli bakteriler ile sağlık çalışanının tekrar kendisine, hastalara ve topluma bulaşabilir (Banawas ve ark., 2018). Sağlık personelinin el hijyenine uyum sorunu ve telefonlarını dezenfektan ile temizleme konusundaki eksiklikleri, akıllı telefonlara antimikrobiyal özellik kazandırılması görüşünü ortaya çıkarmıştır. Nitekim akıllı telefonlardaki bakteriyel 
kontaminasyona karşı koruyucu önlemlerin geliştirilmesi gerektiği de ifade edilmektedir (Ülger ve ark., 2009).

Sağlık çalışanlarının telefonlarının koruma malzemelerine (telefon koruma ve ekran koruyucu) antimikrobiyal özellik kazandırılması amacıyla gerçekleştirilen bu çalışmada, telefon koruma malzemelerinin fiziksel ve kimyasal özellikleri araştırılmış ve diğer yöntemlere oranla avantajları göz önünde bulundurularak çevre dostu atmosferik plazma teknolojisi yöntem olarak belirlenmiştir. Atmosferik plazma; düşük sıcaklıklarda güçlü bir sterilizasyon sağlayabilmesi, polimer yüzeye yapışan mikroorganizmaları kısa sürede etkili bir şekilde inaktif edebilmesi, kimyasal ve su içermemesi, daha az enerji tüketimine neden olması, düşük maliyetli olması, koruma malzemesinin yapısına etki etmemesi, toksik atı bırakmadığından zararsız ve çevre dostu olması, plastik materyalleri kalıntı bırakmadan hızlıca sterilize etmesi nedeniyle avantajlı bir yöntemdir (Yasuda, 1984; Yangılar ve Oğuzhan, 2013). Laboratuvar koşullarında oluşturulabilen plazmalar termodinamik özelliklerine göre sıcak ve soğuk plazmalar diye sınıflandırılmaktadır (Fridman ve ark., 2007). Sürekli plazma ortamı sağlamak için en yaygın olarak kullanılan yöntem, “elektriksel boşalım”dır. Elektriksel yük boşalımıyla oluşturulan plazma genelde "soğuk atmosferik plazma" olarak adlandırılmaktadır. Soğuk atmosferik plazma kontamine olan yüzeylerin dekontaminasyonu, materyallerin yüzey işlenmesi, tıbbi aletlerin sterilizasyonu, gıda güvenliğinin sağlanması gibi birçok alanda kullanılmaktadır. Soğuk atmosferik plazma sistemleri birçok vejetatif gram negatif ve gram pozitif bakteriler, mayalar, küfler ve endosporların dekontaminasyonunda başarılı bir şekilde kullanılmaktadır (Rod ve ark., 2012).

Hastane ortamında enfeksiyonların yayılımını engellemek için hastalar ve sağlık çalışanlarına yönelik antimikrobiyal özellik kazandırılmış ürünler (hasta ve personel tekstil ürünleri, araç ve gereçler) kullanılmaktadır. Ancak bakteriyel yükü fazla olan akıllı telefonlara antimikrobiyal özellik kazandırılmasına yönelik çalışmalara rastlanmamıştır. $\mathrm{Bu}$ çalışmada sağlık personelinin sürekli temas halinde bulunduğu farklı malzemelerden üretilmiş cep telefonu korumalarına (TPU, PC, PLA) ve ekran koruyuculara antimikrobiyal özellik kazandırılması amacıyla atmosferik plazma yöntemi kullanılmıştır. Geliştirilen antimikrobiyal telefon koruma malzemesinin nozokomiyal enfeksiyonların önlemesine sağlayacağı katkının yanı sıra enfeksiyon gelişme riski nedeniyle hastane ortamında veya evinde uzun süre diğer insanlardan izole yaşayan hastalar (kemoterapi alan, immün yetmezliği olan) için de koruyucu bir araç olabileceği düşünülmektedir. Bu araştırma ile antimikrobiyal özellik kazandırılan telefon koruma malzemeleri ile gelecekte üretilecek cep telefonu koruma ve ekran koruyucuların sağlık çalışanlarının kullanımına sunulmasıyla birlikte nozokomiyal enfeksiyonların sıklığının azaltılması, çapraz enfeksiyon riskinin engellenmesi, toplumdaki her bir bireyin olası patojenlerle karşılaşma riskinin azaltılması hedeflenmektedir.

\section{Materyal ve Metot}

Bu çalışmada, tam teşekküllü bir hastanede çalışan 40 sağlık personelinin $\left(n_{\text {hemşire }}=10\right.$ ve $n_{\text {doktor }}=10, n_{\text {idari personel }}=10$ ve $n_{\text {yardımc }}$ personel=10) bireysel hijyen ve akıllı telefon kullanım özellikleri belirlenmiştir. Çalışmaya katılan 40 sağlık çalışanının akıllı telefonlarının yüzeylerinden jelli ve jelsiz eküvyon ile örnek alınmıştır. Yüzey örnekleri katılımcıların telefonundan yaklaşık 6-7 saat sürede toplanmıştır. Örnekler katılımcıların telefonunun $1 \mathrm{~cm}^{2}$ 'lik yüzey alanından alınmıştır. Steril serum fizyolojik içerisindeki jelsiz eküvyonlar ve jelli eküvyonlar bekletilmeden laboratuvara getirilerek, mikrobiyolojik yüklerinin belirlenmesi için kanlı agar (\%5 koyun kanlı) ve EMB (Eosin Methylen Blue) agara ekimleri yapilarak $37^{\circ} \mathrm{C}$ derecede 24 saat inkübasyona bırakılmıştır. İnkübasyon süresi sonunda üremeler incelenerek identifikasyon için gram boyama, biyokimyasal (katalaz ve koagülaz) ve metisilin direnç deneyleri yapılmıştır. Metisilin direnç testi için disk difüzyon testi kullanılarak, örnekler Muller Hinton agara yayma ekim yapılıp (McFarland $0,5 \quad\left(10^{8}\right.$ cfu/ml)standard1) sefoksitin (30 mg Oxoid) diski konularak $35^{\circ} \mathrm{C}$ da 18-24 saat inkübasyona birakılmış ve süre sonunda inhibisyon zon çapları kumpas ile ölçülerek sonuçlar CLSI (Clinical and Laboratory Standards Institute) kriterlerine göre; $<21 \mathrm{~mm}$ olanlar dirençli, $>22 \mathrm{~mm}$ olanlar metisiline duyarlı olarak değerlendirilmiştir (Wayne, 2011).

\subsection{Malzeme seçimi}

\subsubsection{Cep Telefon Koruma Malzemeleri}

Çalışma kapsamında kullanılan cep telefonu koruma malzemeleri iki farklı şekilde temin/elde edilmiştir. Birinci grup cep telefonu koruma malzemeleri 3D yazıcı ile Termoplastik Poliüretan (TPU) ve Polilaktik Asit (PLA) filament'den $0,5 \mathrm{~mm}$ ve $1,0 \mathrm{~mm}$ kalınlığında üretilmiştir. $\mathrm{Bu}$ telefon koruma

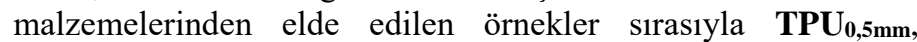
TPU $_{1 \mathrm{~mm}}$, PLA $_{0,5 \mathrm{~mm}}$, PLA $_{1 \mathrm{~mm}}$ olarak adlandırılmıştır. $\underline{\text { Ikinci grup }}$ cep telefonu koruma malzemeleri ticari olarak temin edilen 3 farklı malzemeden PC $^{\circledR}$ (Polikarbonat), TPU ${ }^{\circledR}$ ve TPU/silikon ${ }^{\circledR}$ üretilmiş ürünler satın alma yoluyla temin edilmiş ve kullanılmıştır. $\mathrm{Bu}$ ticari telefon koruma malzemelerinden elde edilen örnekler sırasıyla PC $^{\circledR}$, TPU ${ }^{\circledR}$ ve TPU/silikon ${ }^{\circledR}$ olarak adlandırılmıştır.

\subsubsection{Ekran Koruyucu Malzemeleri}

Çalışmada ticari olarak temin edilerek kullanılan $0,5 \mathrm{~mm}$ nanocam (9H) ve temperli cam (flexibleglass 6D) ekran koruyucular değerlendirilmiştir. Bu ekran koruyuculardan elde edilen örnekler sırasıyla nano $^{\circledR}$ ve flexi $^{\circledR}$ olarak adlandırılmıştır. Toplam 9 farklı örnek 3 bakteri tipi için $($ deney=27, kontrol=27) hazırlanmıştır. Örnekler $1 \mathrm{~cm}$ çapında steril olarak kesilerek deneyler için hazırlanmıştır.

\subsection{Atmosferik Plazma Yöntemiyle Yüzey Modifikasyonu}

$\mathrm{Bu}$ çalışma kapsamında kullanılan yüzey modifikasyonu yöntemi, yüzey özelliklerinin değiştirilmesinde sıklıkla kullanılan elektriksel boşalım (glow discharge) yöntemidir. $\mathrm{Bu}$ işlemin amacı yüzey adsorbsiyon kapasitesinin arttırılmasıdır. Atmosferik plazma sistemi kullanılarak deney grubundaki 27 örnek 1 dakika süre ile 3 amper elektriksel boşalım yöntemi ile etkileştirilerek yüzey pürüzlendirilmiştir (Şekil 4) (Koçum C. ve Ayhan H. 2007), (Koçum C. ve ark. 2010) Kontrol grubu örneklere herhangi bir işlem uygulanmamıştır.

Örneklerin ortamda inert kalmasını sağlamak amacıyla argon gazı kullanılmıştır. Atmosferik plazmadan geçirilerek sterilitesi bozulmadan, argon gazı ortamında, örneklerin bir sonraki aşama olan besi yeri ekim aşamasına geçilmiştir. 


\subsection{Malzeme Karakterizasyonu}

\subsubsection{Cep Telefon Koruma Malzemesi}

Çalışma kapsamında kullanılan TPU $\mathrm{T}_{0,5 \mathrm{~mm}}, \mathrm{TPU}_{1 \mathrm{~mm}}$, $\mathrm{PLA}_{0,5 \mathrm{~mm}}, \mathrm{PLA}_{1 \mathrm{~mm}}, \mathrm{PC}^{\circledR}, \mathrm{TPU}^{\circledR}$, TPU/silikon ${ }^{\circledR}, 7$ farklı telefon koruma malzemelerinin karakterizasyonu çerçevesinde ATRFTIR spektrumları alınmıştır. ATR-FTIR spektrumları plazma öncesi ve sonrasında alınarak karşılaştırmalı olarak irdelenmiştir.

\subsubsection{Ekran Koruyucu Malzemesi}

Çalışma kapsamında kullanılan nano $^{\circledR}$ ve flexi $^{\circledR}, 2$ farklı ekran koruyucu malzemesinin karakterizasyonu çerçevesinde ATR-FTIR spektrumları alınmıştır. ATR-FTIR spektrumları plazma öncesi ve sonrasında alınarak karşılaştırmalı olarak irdelenmiştir.

\subsection{Cep Telefon Koruma Malzemelerinin Antimikrobiyal Özelliklerinin Belirlenmesi}

Telefon yüzeylerinden izole edilen 3 tür bakteri (E.coli, metisiline dirençli S.aureus, S.pyogens) Müller Hinton agara yayma ekim tekniği ile inoküle edilmiştir. Çalışma kapsamında bulunan 9 farklı telefon koruma ve ekran koruyucu materyalin her biri için 3 farklı mikroorganizmanın ekilebileceği besiyeri de hazırlanmıştır.

Atmosferik plazma uygulanan $1 \mathrm{~cm}$ çapında kesilmiş 27 adet örnek aseptik koşullarda agar yüzeyine yerleştirilmiştir. Kontrol amaçlı olarak ise işlem görmemiş diskler kullanılmıştır. Petri kutuları $37^{\circ} \mathrm{C}$ da 24 saat inkübe edilerek süre sonunda oluşan inhibisyonzonları ölçülerek değerlendirilmiştir.

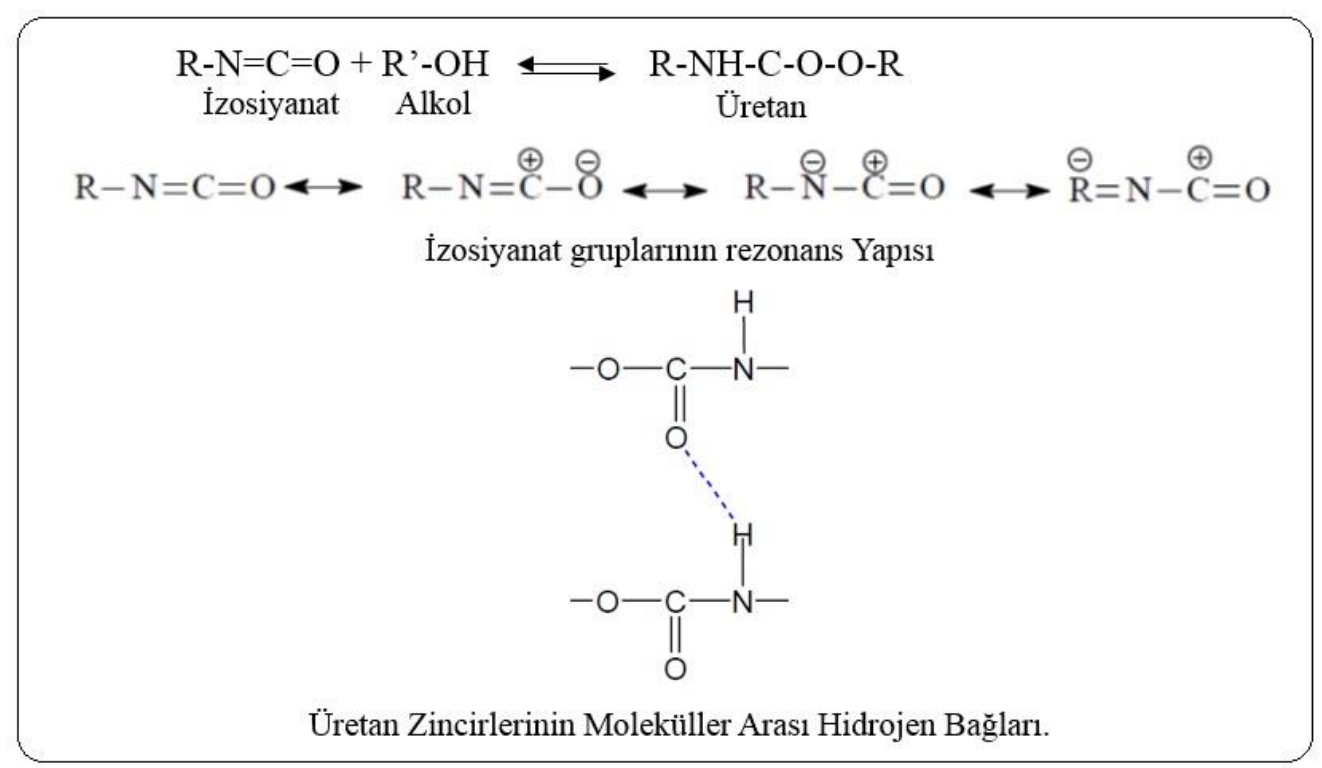

Şekil 1. TPU sentezi ve yapısı.

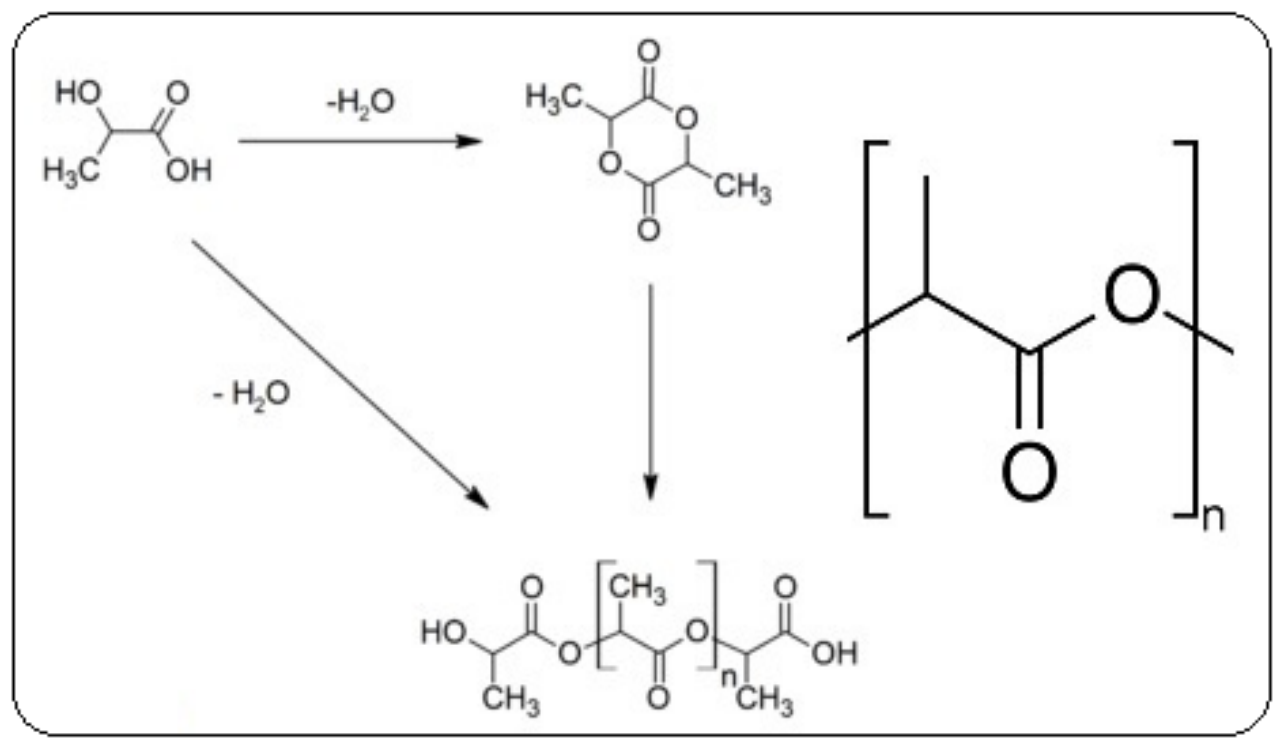

Şekil 2. PLA sentezi ve yapist. 


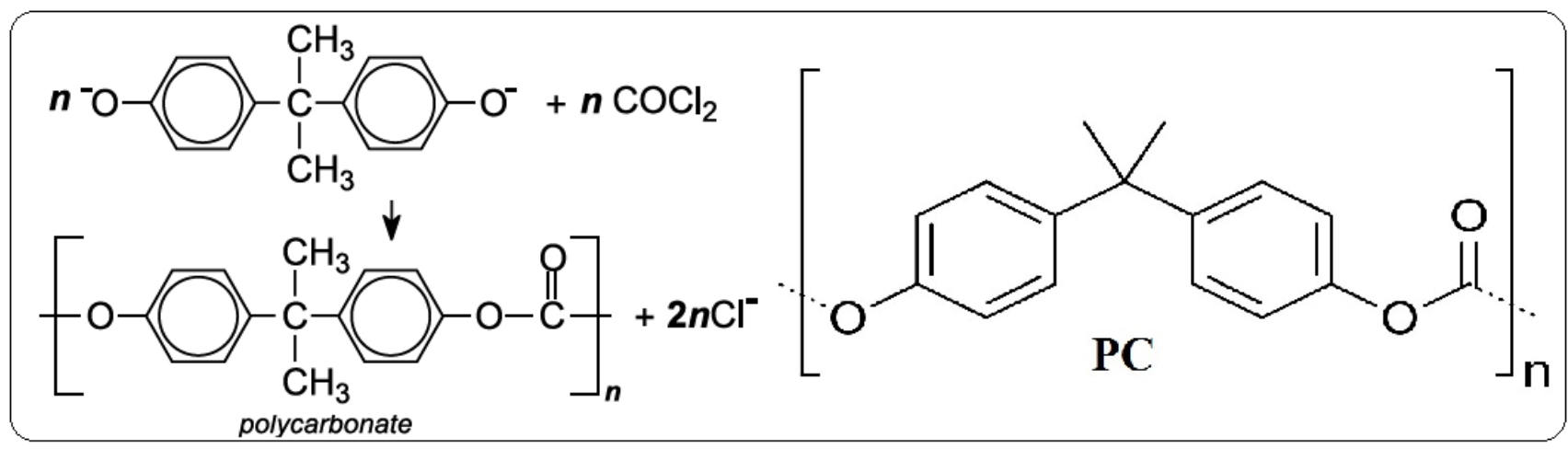

Şekil 3. Polikarbonat sentezi ve yapısı.

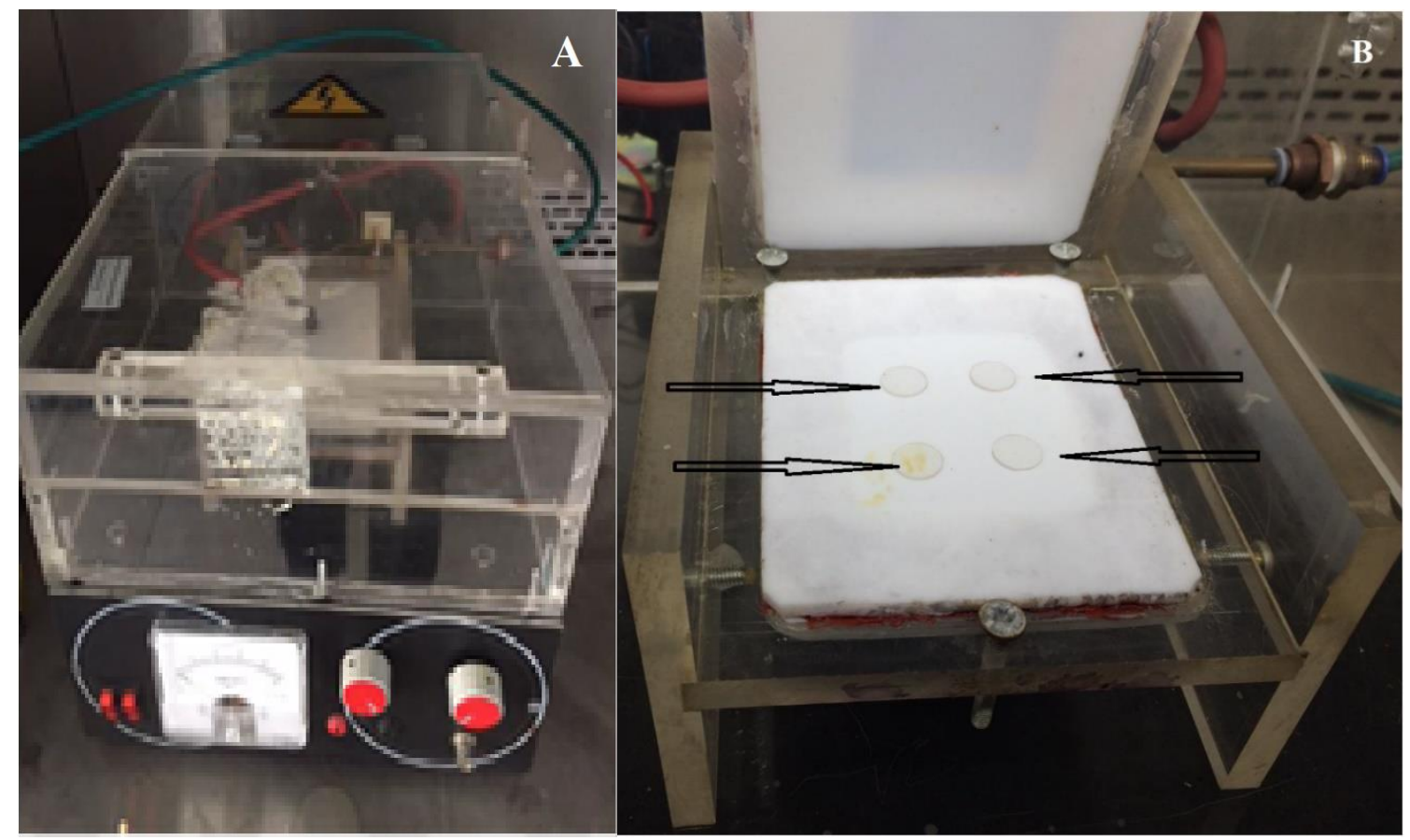

Şekil 4. (A) Soğuk atmosferik plazma cihazı, (B) Atmosferik plazma cihazına yerleştirilmiş örnek görüntüleri.

\section{Araştırma Sonuçları ve Tartışma}

Bu çalışmada 9 farklı malzemeden örnekler $1 \mathrm{~cm}$ çapında kesilerek deney ve kontrol olmak üzere 2 grupta hazırlanmıştır. $\mathrm{Bu}$ işlem 3 bakteri türü için de yapılmıştır. Tüm malzemeler hazırlanmadan önce kumpas ile kalınlıkları ölçülmüştür.

Bu çalışmaya katılan sağlık çalışanlarının \%80’i kadın olup, $\% 62.5$ 'i hastanenin dahili birimlerinde çalışmaktadır. Sağlık çalışanlarının \%35'i hastalar ile temas halinde iken telefon kullandığını, \%87.5'i akıllı telefonunun hastane yüzeyleri ile temas ettiğini, \%40.0’1 tuvalette telefon kullandığını belirtmiştir. Ayrıca bu çalışmaya katılan sağlık çalışanlarının \%35'i cep telefonunu düzenli olarak temizlediğini, $\% 62.5$ 'i telefonunu hiç temizlemediğini, akıllı telefonunu temizleyenlerin \%60'1 temizleme yöntemi olarak ıslak mendil kullandığını ifade etmiştir. Bu çalışmada cep telefonuna dokunmadan önce ellerini yıkayan sağlık çalışanlarının oranı \%27.5, hasta ile temastan sonra ellerini yıkayanların oranı $\% 90.0$ ve ellerini sıvı sabun ile yıkayanların oranı \%60’dır. Bu çalışmada sağlık çalışanlarının günlük cep telefonu kullanma süresi ortalaması $245.25 \pm 192.62$ dakika, hastane ortamında telefon ile temas süresi ortalaması $130.75 \pm 136.3$ dakikadır. Hastane ortamı ve sağlık çalışanlarını odağına alan çalışmalar gözden geçirildiğinde; hijyenik e-ISSN: 2148-2683 özelliklerdeki eksiklikler nedeniyle akıllı telefonların bir enfeksiyon taşıma aracı haline geldiği ve koruma malzemelerinin bu konudaki önemine vurgu yapıldığ görülmektedir (Colum ve ark. 2017). Bununla birlikte sağlık personelinin \%76.2'sinin kullandığı telefonların bir enfeksiyon kaynağı olduğunun farkında olmalarına rağmen iş (\%77.9) ve tuvalet $(\% 43.5)$ ortamında telefon kullandıklarını ve önemli bir kısmının telefonunu temizlemedikleri (\%44.9) belirlenmiştir (Banawas et. al 2018). $\mathrm{Bu}$ bilgiler hastane ortamında enfeksiyonu önleyici farklı müdahalelere gereksinim olduğunu düşündürmektedir.

Yapılan çalışma sonucunda; yüzey örnekleme ile alınan 40 örnekten 36'sında (\%90) üreme olmuştur (Tablo-2). Üreme olan örneklerde kanlı agarda toplam $7(\% 19,4)$ hemoliz saptanmıştır. Hemoliz saptananların 5'i $(\% 71,4) \beta$-hemoliz, 2'si $(\% 28,6) \alpha$ hemoliz olarak belirlenmiştir. $\beta$-hemoliz yapan örneklerin 2 'si $(\% 40,0)$ metisilin duyarlı S.aureus, 1 'i $(\% 20,0)$ ise metisilin dirençli S.aureus ve 2'si $(\% 40,0)$ S.pyogenes olarak tespit edilmiştir. $\alpha$-hemoliz görülen 2 örnek $(\% 100,0) \alpha$-hemolitik Streptococ (Viridans streptococ) olarak değerlendirilmiştir. Kanlı agarda üreyen ancak hemoliz oluşturmayan örnekler (nonhemolitik) $(\% 80,6)$ hemolitik olmayan Streptococlar olarak belirlenmiştir. Gram boyama sonucunda pozitif sonuç veren 
örnekler katalaz ve koagülaz testlerine tabi tutularak Streptococcus spp. ve Staphylococcus spp. olarak ayırımları yapılmıştır. Gram boyama testinde negatif sonuç veren örnekler ise E.coli ve diğer Enterobacter olarak değerlendirilmiştir. Literatürler değerlendirildiğinde mikroorganizmaların çoğalması ile ilgili elde edilen sonuçlar, çalışma sonuçlarımızla benzerlik göstermektedir. Birçok çalışmada sağlık çalışanlarının telefonlarında kendi cilt florasının dışında farklı türlerde patojen mikroorganizmaların bulunduğu tespit edilmiştir (Alpay ve ark. 2015; Kotris ve ark 2016, Zakai ve ark, 2016, Chang ve ark. 2017).

\subsection{Atmosferik Plazma Yöntemiyle Yüzey Modifikasyonu}

Sağlık çalışanlarının akıllı telefonlarındaki koruma malzemelerine antimikrobiyal özellik kazandırılması amacıyla gerçekleştirilen bu çalışmada; atmosferik plazma yöntemiyle yüzey modifikasyonu sağlanan koruma malzemelerinin tamamının farklı düzeylerde antimikrobiyal özellik kazandığ bulunmuştur. Deney grubundaki $1 \mathrm{~cm}$ çapındaki tüm örneklerin inhibisyon zonu oluşturduğu, işlenmemiş (kontrol grubu) örneklerde ise zon oluşumunun sadece disk çapı kadar olduğu gözlenmiştir. Bu çalışmada 3 amper 1 dakika süre ile uygulanan plazma modifikasyonu sonucunda etkin antimikrobiyal aktivite saptanmıştır.

Tablo-2. Sağlık çalışanlarının telefon yüzeylerinden alınan örneklerde üreme durumu. (n=40)

\begin{tabular}{|l|c|c|}
\hline Telefon yüzeylerinden alınan örneklerde üreme & $\mathbf{n}$ & $\mathbf{\%}$ \\
\hline Var & 36 & 90.0 \\
\hline Yok & 4 & 10.0 \\
\hline Telefon yüzeylerinden izole edilen bakteriler * & & \\
\hline Non hemolitik Streptococus spp. & 29 & 72.5 \\
\hline Enterobakter & 11 & 27.5 \\
\hline Metisilin duyarll S.aureus & 2 & 5.0 \\
\hline a-hemolitik Streptococcus spp. & 2 & 5.0 \\
\hline S.pyogenes & 2 & 5.0 \\
\hline Metisilin dirençli S.aureus & 1 & 2.5 \\
\hline E.coli & 1 & 2.5 \\
\hline
\end{tabular}

*Bazı sağlık çalışanlarının telefonunda birden fazla türde bakteri üremiş, yüzdeler n sayısı üzerinden alınmıştır

\subsection{Malzeme Karakterizasyonu}

\subsubsection{Telefon Koruma Malzemeleri}

\subsubsection{TPU ${ }^{\circledR} A T R-F T-I R$ Spektrumlart}

Termoplastik poliüretandan üretilmiş telefon koruma malzemelerin ATR-FTIR spektrumları incelendiğinde; işlem görmüş yüzeylerde, işlem görmemiş malzeme yüzeylerinde görülmeyen 3 farklı fonksiyonel grubun oluştuğu gözlemlenmiştir.

$3700-3800 \mathrm{~cm}^{-1}$ dalga boyunda monosubstitueamid R-NHCO- gerilme piki görülmüştür. $2160 \mathrm{~cm}^{-1}$ ve $2022 \mathrm{~cm}^{-1}$ dalga boylarında izosiyanat $(\mathrm{R}-\mathrm{N}=\mathrm{C}=\mathrm{O})$ yapısında $=\mathbf{C}-\mathbf{O}$ gerilme titreşimi gözlenmiştir. $\mathrm{Bu}$ gözlenen gerilme titreşimleri $\mathrm{TPU}_{\mathbb{B}}$ yapısında amid yapısından bir sübstitüentin koptuğunu, izosiyanat yapıdan da bir çift bağın koparak tek bağ oluşumu kimyasal değişimlerini işaret etmektedir (Şekil 5).

\subsubsection{TPU/Silikon ${ }^{\circledR}$ ATR-FT-IR Spektrumlart}

Termoplastik poliüretan/silikon karışımından üretilmiş telefon koruma malzemelerin ATR-FTIR spektrumları incelendiğinde; işlem görmüş yüzeylerde, işlem görmemiş malzeme yüzeylerinde görülmeyen 2 farklı fonksiyonel grubun oluştuğu gözlemlenmiştir. Yine $3700-3800 \mathrm{~cm}^{-1}$ dalga boyunda monosubstitueamid R-NH-CO- gerilme piki görülmüştür. 1726 $\mathrm{cm}^{-1}$ ve $1702 \mathrm{~cm}^{-1}$ dalga boylarında -C-O gerilme pik şiddetinin önemli ölçüde arttığı tespit edilmiştir. Görülen bu değişiklikler; amid yapısından bir sübstitüentin koptuğunu, izosiyanat yapıdan da bir çift bağın koparak tek bağ oluşumu kimyasal değişimleri ifade etmektedir.

\subsubsection{PC ${ }^{\circledR}$ ATR-FT-IR Spektrumlart}

Polikarbonat polimerinden üretilmiş telefon koruma malzemelerin ATR-FTIR spektrumları incelendiğinde; işlem görmüş yüzeylerde, işlem görmemiş malzeme yüzeylerinde görülmeyen 2 farklı fonksiyonel grubun oluştuğu gözlemlenmiştir. 3613-3502 $\mathrm{cm}^{-1}$ dalga boylarında -O-H gerilme pikleri görülmüştür.

$\mathrm{Bu}$ durum polimerin yapısında var olan $-\mathrm{C}=\mathrm{O}$ bağlarının protonlanarak -C-O-H bağına dönüştüğünü, yapının hidrofilik özellik kazandığını göstermektedir. Aynı zamanda işlem görmemiş yüzey ATR-FTIR spektrumunda $2921 \mathrm{~cm}^{-1}$ dalga boyunda var olan -C-H bağlarının azaldığ gözlemlenmiştir (Şekil 7).

FTIR analizlerinde parmak izi bölgesi olarak tanımlanan $1500 \mathrm{~cm}^{-1}$ dalga boyunun aldındaki bölgede fazla sayıda pik oluşumu gözlenmektedir. Bu bölgede oluşan pikler ayırt edici özellikte olmadıkları için değerlendirme kapsamına alınmamıştır.

\subsubsection{TPU ${ }_{0,5 m m} A T R-F T-I R$ Spektrumlart}

3D yazıcı ile özel olarak ürettirilen $0,5 \mathrm{~mm}$ kalınlığındaki Termoplastikpoliüretan'dan üretilmiş telefon koruma malzemelerin ATR-FTIR spektrumları incelendiğinde; işlem görmüş yüzeylerde, işlem görmemiş malzeme yüzeylerinde 
görülmeyen 1 farklı fonksiyonel grubun oluştuğu gözlemlenmiştir. 3700-3800 $\mathrm{cm}^{-1}$ dalga boyunda monosubstitueamid R-NH-CO- gerilme piki görülmüştür. Amid yapısından bir sübstitüentin koptuğunu göstermektedir (Şekil 8).

\subsubsection{TPU ${ }_{1 m m}$ ATR-FT-IR Spektrumlart}

3D yazıcı ile özel olarak ürettirilen $1 \mathrm{~mm}$ kalınlığındaki Termoplastikpoliüretan'dan üretilmiş telefon koruma malzemelerin ATR-FTIR spektrumları incelendiğinde; işlem görmüş yüzeylerde, işlem görmemiş malzeme yüzeylerinde görülmeyen 1 farklı fonksiyonel grubun oluştuğu gözlemlenmiştir. 3700-3800 $\mathrm{cm}^{-1}$ dalga boyunda monosubstitueamid R-NH-CO- gerilme piki görülmüştür. Amid yapısından bir sübstitüentin koptuğunu göstermektedir. $2160 \mathrm{~cm}^{-1}$ ve $2026 \mathrm{~cm}^{-1}$ dalga boylarında izosiyanat $(\mathrm{R}-\mathrm{N}=\mathrm{C}=\mathrm{O})$ yapısinda
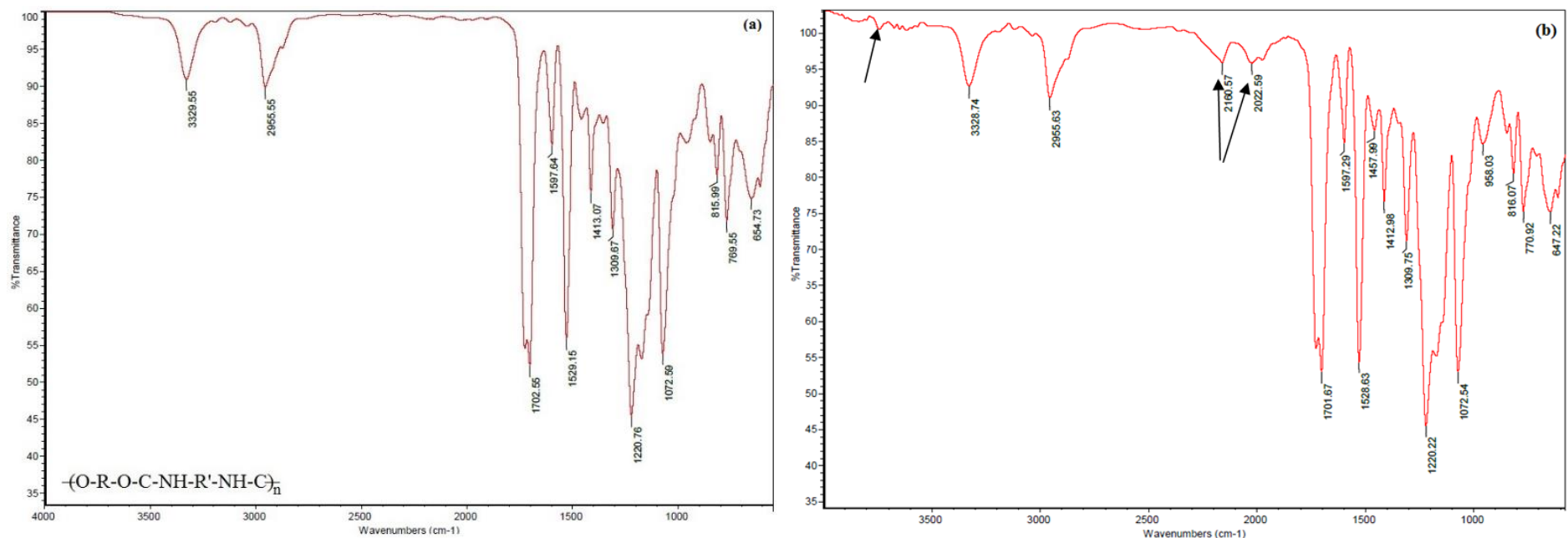

Şekil 5. TPU $U^{\circledR}$ yüzey ATR-FTIR spektrumlarl; (a) Plazma öncesi; (b) Plazma sonrası.
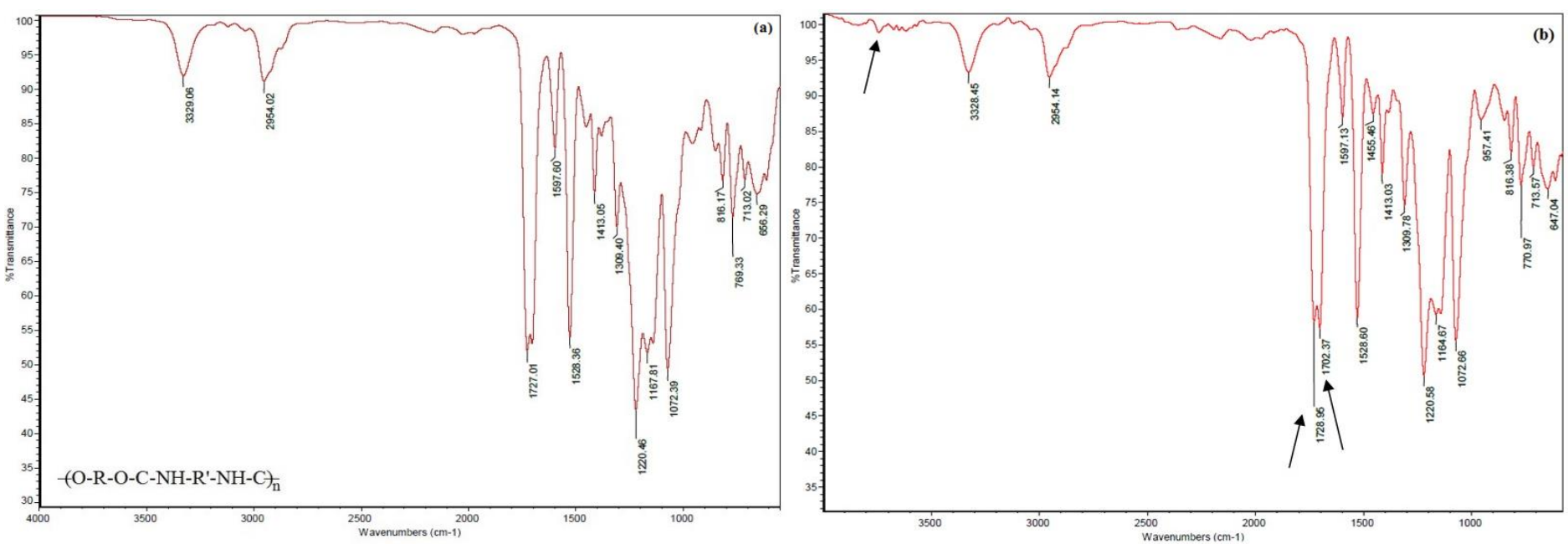

Şekil 6. TPU/Silikon ${ }^{\circledR}$ yüzey ATR-FTIR spektrumlarl; (a) Plazma öncesi; (b) Plazma sonrast.
=C-O gerilme titreşimi gözlenmiştir. $\mathrm{Bu}$ gözlenen gerilme titreşimleri $\mathrm{TPU}_{\mathbb{B}}$ yapısında izosiyanat yapıdan da bir çift bağın koparak tek bağ oluşumu kimyasal değişimlerini işaret etmektedir (Şekil 9). 

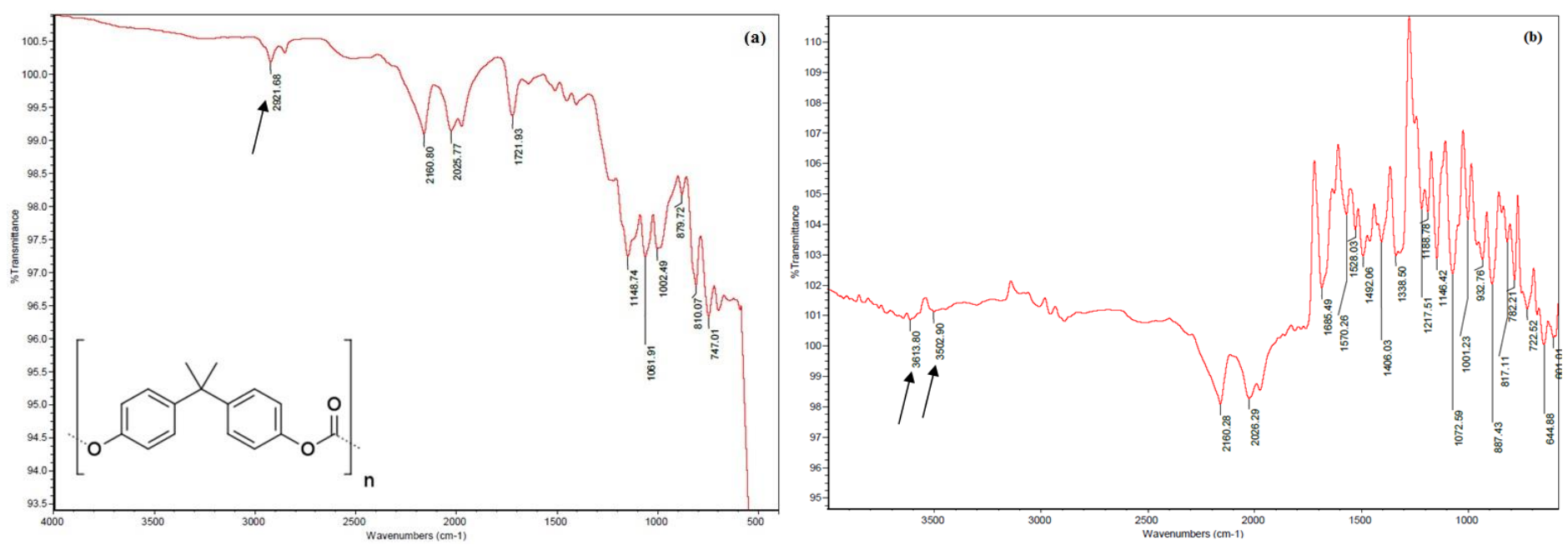

Şekil 7. PC ${ }^{\circledR}$ yüzey ATR-FTIR spektrumlarl; (a) Plazma öncesi; (b) Plazma sonrasi.
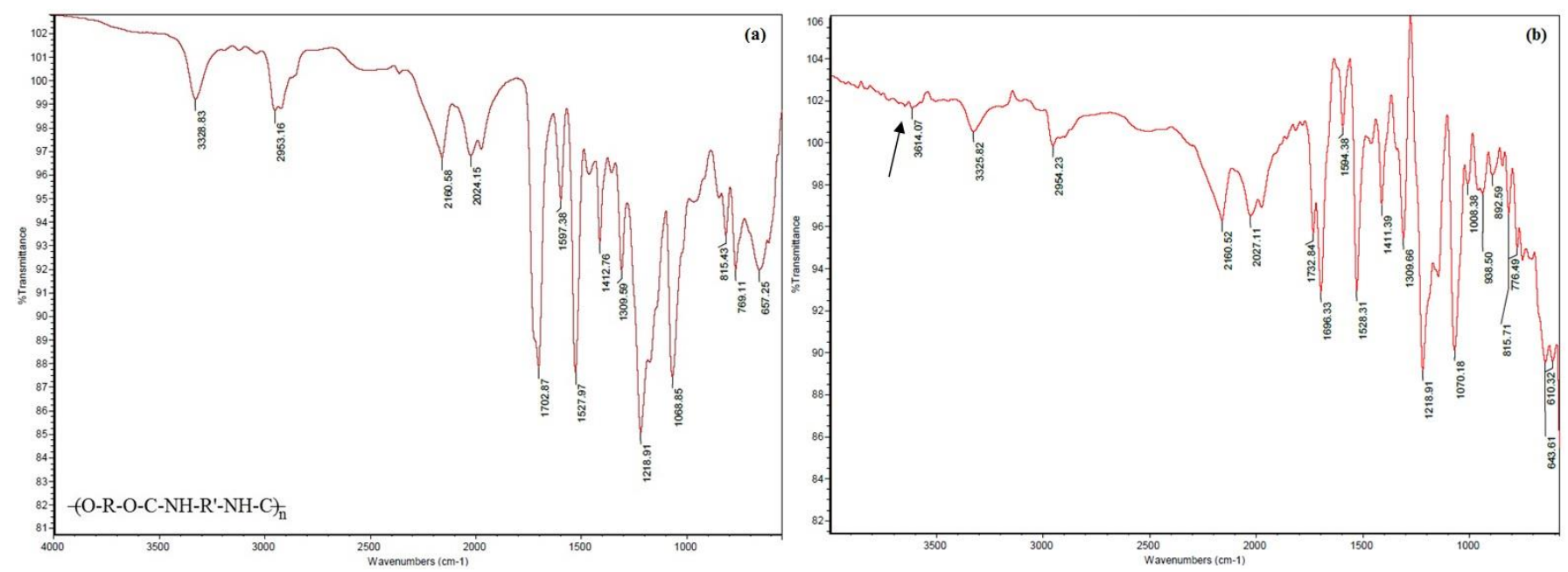

Şekil 8. TPU $U_{0,5 m m}$ yüzey ATR-FTIR spektrumlarl; (a) Plazma öncesi; (b) Plazma sonrast.
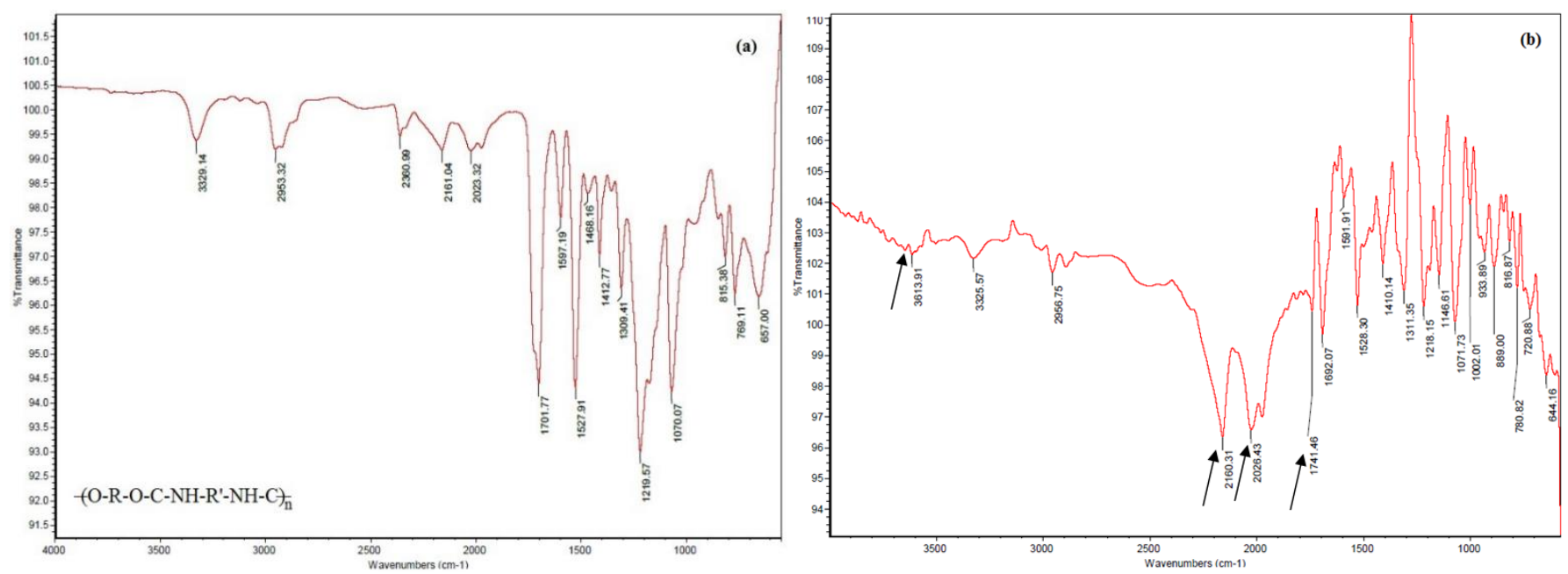

Şekil 9. TPU Imm yüzey ATR-FTIR spektrumları; (a) Plazma öncesi; (b) Plazma sonrası. 

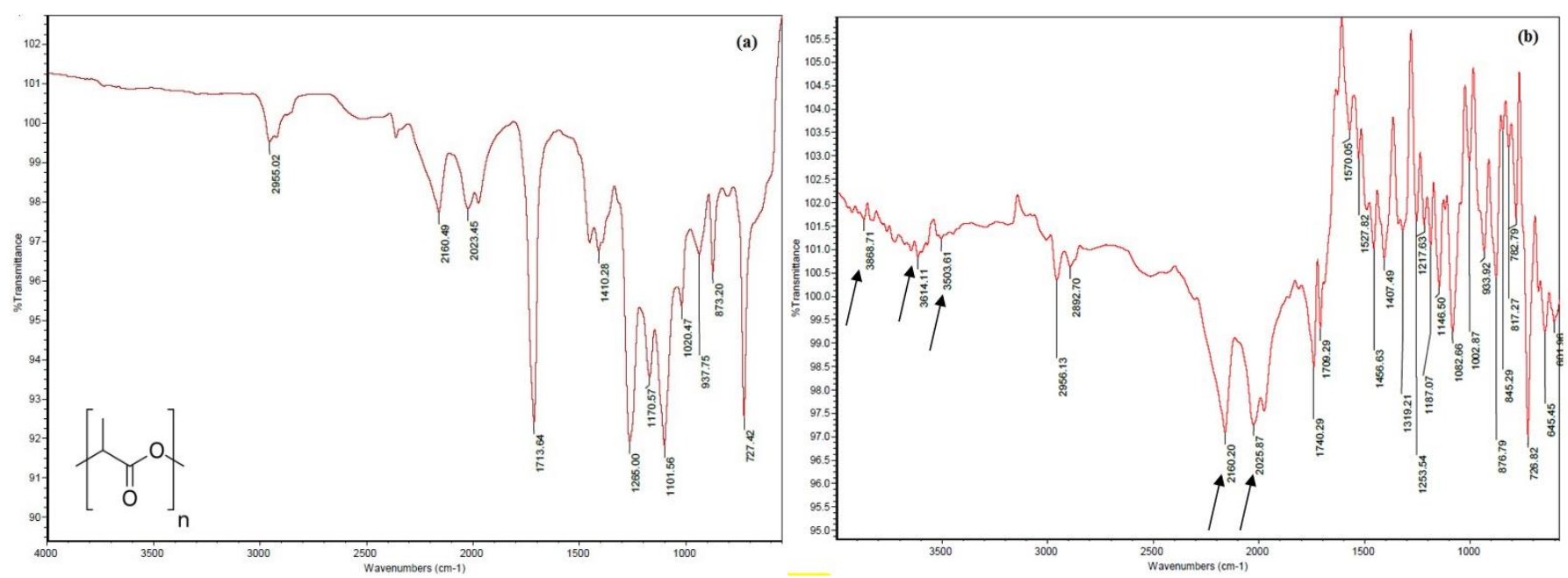

Şekil 10. PLA 0,5mm yüzey ATR-FTIR spektrumlarl; (a) Plazma öncesi; (b) Plazma sonrasl.

\subsubsection{PLA ${ }_{0,5 m m}$ ATR-FT-IR Spektrumlart}

3D yazıcı ile özel olarak ürettirilen $0,5 \mathrm{~mm}$ kalınlığındaki PLA'dan üretilmiş telefon koruma malzemelerin ATR-FTIR spektrumları incelendiğinde; işlem görmüş yüzeylerde, işlem görmemiş malzeme yüzeylerinde görülmeyen 3 farklı fonksiyonel grubun oluştuğu gözlemlenmiştir. 3868-3614-3503 $\mathrm{cm}^{-1}$ dalga boylarında $-\mathrm{O}-\mathrm{H}$ gerilme pikleri görülmüştür. $\mathrm{Bu}$ durum polimerin yapısında var olan $-\mathrm{C}=\mathrm{O}$; $-\mathrm{C}-\mathrm{O}$ bağlarının protonlanarak -C-O-H bağına dönüştüğünü, yapının hidrofilik özellik kazandığını göstermektedir. Aynı zamanda işlem görmemiş yüzey ATR-FTIR spektrumunda $2955 \mathrm{~cm}^{-1}$ dalga boyunda var olan $-\mathrm{C}-\mathrm{H}$ bağlarının azaldığı gözlemlenmiştir. $2160 \mathrm{~cm}^{-1}$ ve $2025 \mathrm{~cm}^{-1}$ dalga boylarında gözlenen gerilme titreşimleri -C-O gerilme titreşimi, çift bağın koparak tek bağ oluşumu kimyasal değişimlerini işaret etmektedir (Şekil 10).

\subsubsection{PLA ${ }_{\text {Imm }}$ ATR-FT-IR Spektrumlart}

3D yazıcı ile özel olarak ürettirilen $1 \mathrm{~mm}$ kalınlığındaki PLA'dan üretilmiş telefon koruma malzemelerin ATR-FTIR spektrumları incelendiğinde; işlem görmüş yüzeylerde, işlem görmemiş malzeme yüzeylerinde görülmeyen 2 farklı fonksiyonel grubun oluştuğu gözlemlenmiştir. 3868-3614-3503 $\mathrm{cm}^{-1}$ dalga boylarında $-\mathrm{O}-\mathrm{H}$ gerilme pikleri görülmüştür. $\mathrm{Bu}$ durum polimerin yapısında var olan $-\mathrm{C}=\mathrm{O}$; $-\mathrm{C}-\mathrm{O}$ bağlarının protonlanarak -C-O-H bağına dönüştüğünü, yapının hidrofilik özellik kazandığını göstermektedir. $2160 \mathrm{~cm}^{-1}$ ve $2025 \mathrm{~cm}^{-1}$ dalga boylarında gözlenen gerilme titreşimleri -C-O gerilme titreşimi, çift bağın koparak tek bağ oluşumu kimyasal değişimlerini işaret etmektedir (Şekil 11).

\subsubsection{Ekran Koruyucu Malzemeleri}

\subsubsection{Flexi $^{\circledR}$ ATR-FT-IR Spektrumlart}

Çalışma kapsamında kullanılan flexi ${ }^{\circledR}$, ekran koruyucu malzemesinin karakterizasyonu çerçevesinde ATR-FTIR spektrumları incelendiğinde; işlem görmüş yüzeylerde, işlem görmemiş malzeme yüzeylerinde görülmeyen 2 farklı fonksiyonel grubun oluştuğu gözlemlenmiştir. $3800-3500 \mathrm{~cm}^{-1}$ dalga boylarında geniş $-\mathrm{O}-\mathrm{H}$ gerilme pikleri görülmüştür. $\mathrm{Bu}$ durum polimerin yapısında var olan $-\mathrm{C}=\mathrm{O}$; $-\mathrm{C}-\mathrm{O}$ bağlarının protonlanarak -C-O-H bağına dönüştüğünü, su pikinin oluşumunu, böylece yapının hidrofilik özellik kazandığını göstermektedir. Aynı zamanda işlem görmemiş yüzey ATR-FTIR spektrumunda $2900 \mathrm{~cm}^{-1}$ dalga boyunda var olan -C-H bağlarının arttığı ve genişlediği gözlemlenmiştir. $1700 \mathrm{~cm}^{-1}$ dalga boyunda -C-O gerilme pik şiddetinin önemli ölçüde arttığı tespit edilmiştir. Görülen bu değişiklikler cam yüzey yapısında kimyasal değişimleri ifade etmektedir.

\subsubsection{Nano ${ }^{\circledR}$ ATR-FT-IR Spektrumlart}

Çalışma kapsamında kullanılan Nano $^{\circledR}$, ekran koruyucu malzemesinin karakterizasyonu çerçevesinde ATR-FTIR spektrumları incelendiğinde; işlem görmüş yüzeylerde, işlem görmemiş malzeme yüzeylerinde görülmeyen 3 farklı fonksiyonel grubun oluştuğu gözlemlenmiştir. $3800-3500 \mathrm{~cm}^{-1}$ dalga boylarında geniş $-\mathrm{O}-\mathrm{H}$ gerilme pikleri görülmüştür. $\mathrm{Bu}$ durum polimerin yapısında var olan $-\mathrm{C}=\mathrm{O}$; $-\mathrm{C}-\mathrm{O}$ bağlarının protonlanarak -C-O-H bağına dönüştüğünü, su pikinin oluşumunu, böylece yapının hidrofilik özellik kazandığını göstermektedir. Aynı zamanda işlem görmemiş yüzey ATR-FTIR spektrumunda $2900 \mathrm{~cm}^{-1}$ dalga boyunda var olan -C-H bağlarının arttığı ve genişlediği gözlemlenmiştir. $1700 \mathrm{~cm}^{-1}$ dalga boyunda -C-O gerilme pik şiddetinin önemli ölçüde arttığı tespit edilmiştir. Görülen bu değişiklikler cam yüzey yapısında kimyasal değişimleri ifade etmektedir.

\subsection{Telefon Koruma Malzemelerinin Antimikrobiyal Özellikleri}

Çalışma kapsamında kullanılan $\mathrm{TPU}_{0,5 \mathrm{~mm}}, \quad \mathrm{TPU}_{1 \mathrm{~mm}}$, $\mathrm{PLA}_{0,5 \mathrm{~mm}}, \mathrm{PLA}_{1 \mathrm{~mm}}, \mathrm{PC}^{\circledR}, \mathrm{TPU}^{\circledR}, \mathrm{TPU} / \mathrm{silikon}^{\circledR}, 7$ farkl telefon koruma malzemelerinin ve nano $^{\circledR}$ ve flexi $^{\circledR}, 2$ farklı ekran koruyucu malzemelerinin antimikrobiyal özelliklerinin belirlenmesi çerçevesinde, değerlendirilen $S$. aureus, E. coli ve S. pyogenes için çalışma gerçekleştirilmiştir.

\subsubsection{Telefon Korumalarının Antimikrobiyal Özellikleri}

$\mathrm{TPU}^{\circledR}$ materyali için $S$. aureus, E. coli ve S. pyogenes ile yapılan antimikrobiyal aktivite testlerinin görsel sonuçları verilmiştir (Şekil 14) Çalışma kapsamında değerlendirilen 3 mikroorganizma tipi içinde TPU $^{\circledR}$ örneklerin önemli düzeyde antimikrobiyal özellik gösterdiği bulunmuştur. 
TPU/silikon ${ }^{\circledR}$ plazma modifiye örneklerde S.aureus'da 11 $\mathrm{mm}$, E.coli'de $11 \mathrm{~mm}$ ve S.pyogenes'de $13 \mathrm{~mm}$ inhibisyon zon oluşumu gözlenmiştir (Şekil 15) TPU/silikon ${ }^{\circledR}$ tüm mikroorganizma türlerine karşı antimikrobiyal etki göstermiştir. Ayrıca S. pyogenes'de plazma modifiye TPU/silikon ${ }^{\circledR}$ en güçlü antimikrobiyal etkiyi göstermiştir.

Ticari olarak temin edilen $\mathrm{PC}^{\circledR}$, plazma modifiye örnekte $S$. pyogenes'de 6 mm'lik inhibisyon zonu görülürken, $S$. aureus ve E. coli'de zon oluşumu gözlenmemiştir (Şekil 16) Plazma modifiye $\mathrm{PC}^{\circledR}$ nin en güçlü antimikrobiyal etki gösterdiği bakteri türü $S$. pyogenes olarak bulunmuştur. $\mathrm{TPU}_{0,5 \mathrm{~mm}}$ telefon koruma örneğinde 3 bakteri türü için; besi yerinde üreme olmadığ gözlenmiştir. $\mathrm{Bu}$ durum kontrol grubu örneklerle karşılaştırıldığında deney grubunda zon oluşumunun başladığ 1 tespit edilmiştir (Şekil 17).

$\mathrm{TPU}_{1 \mathrm{~mm}}$ telefon koruma örneğinde üç bakteri türünde de kontrol grubunda zon oluşumu varken plazma modifiye örneğinde zon oluşmamıştır (Şekil 18).
$\mathrm{PLA}_{0,5 \mathrm{~mm}}$ plazma modifiye örneklerde 3 bakteri türünde de kontrol grubu örneklerde zon oluşumu başlamış plazma modifiye örneğinde ise üreme olmadığı gözlenmiştir (Şekil 19).

$\mathrm{PLA}_{1 \mathrm{~mm}}$ plazma modifiye deney örneklerinin 3 bakteri türünü içeren besi yerinde üreme olmadığı gözlenmiştir (Şekil 20).

\subsubsection{Ekran Koruyucuların Antimikrobiyal Özellikleri}

Plazma modifiye Nano $^{\circledR}$ ve Flexi ${ }^{\circledR}$ ekran koruyucuların her ikisinde de $10 \mathrm{~mm}$ çapında inhibisyon zonu oluşmuştur. (Şekil 21 ve Şekil 22).
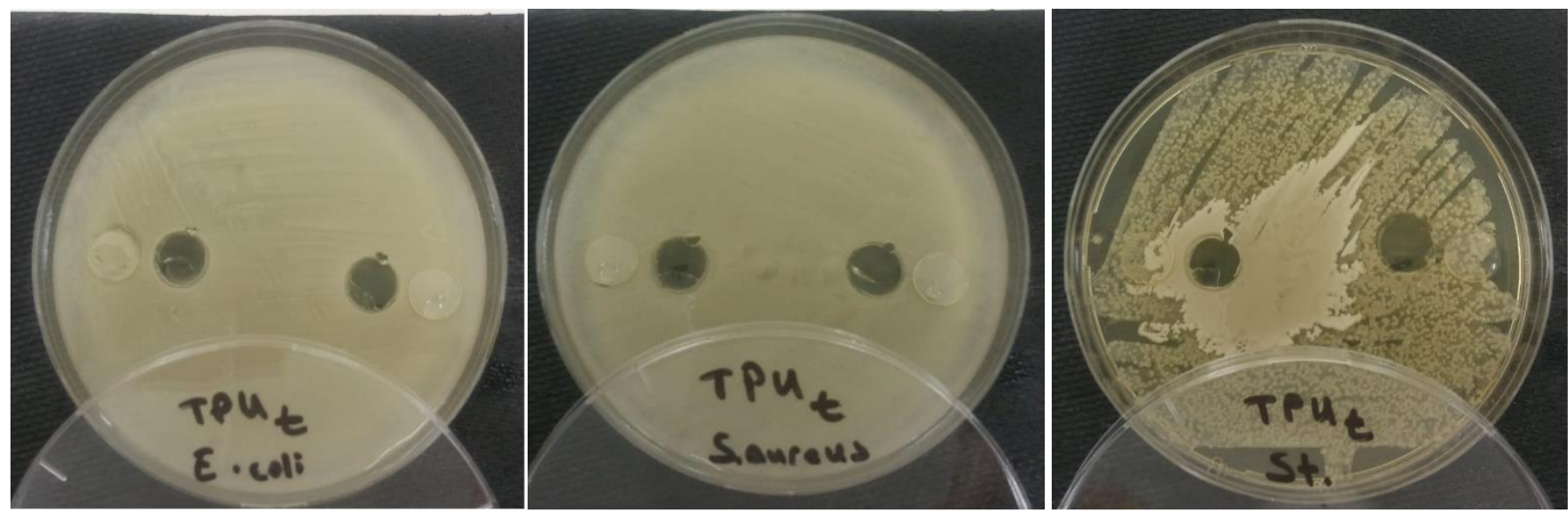

Şekil 14. TPU ${ }^{\circledR}$ telefon korumanın antimikrobiyal özellikleri.
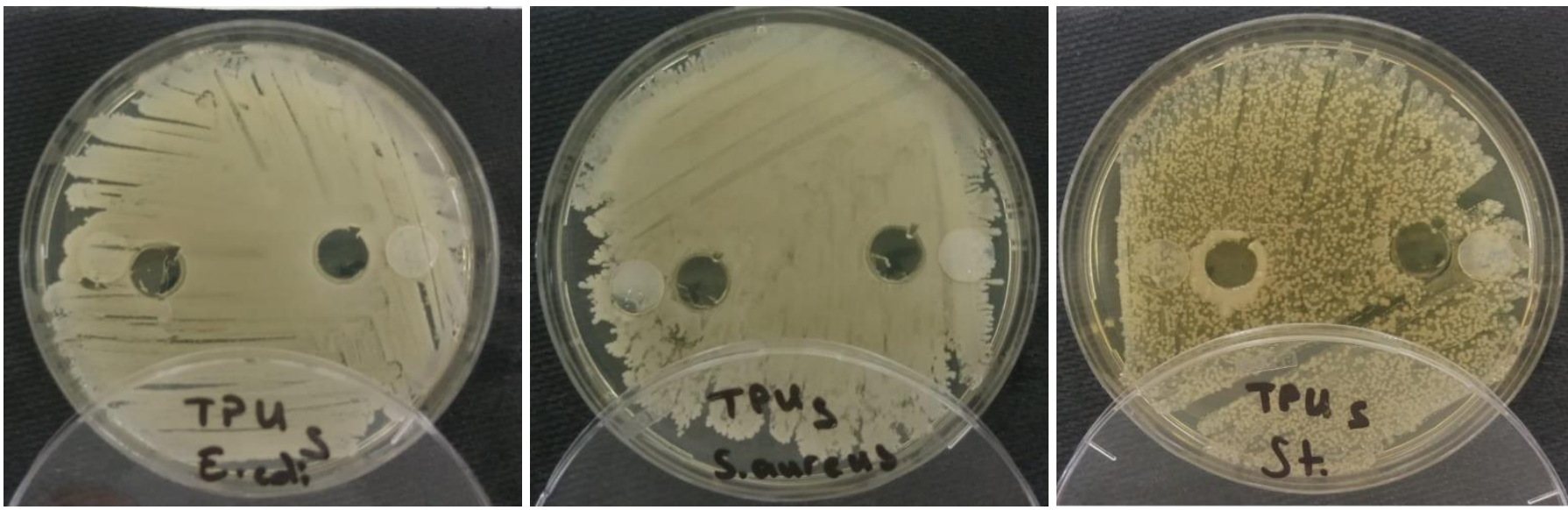

Şekil 15. TPU/silikon ${ }^{\circledR}$ telefon korumanın antimikrobiyal özellikleri. 
European Journal of Science and Technology
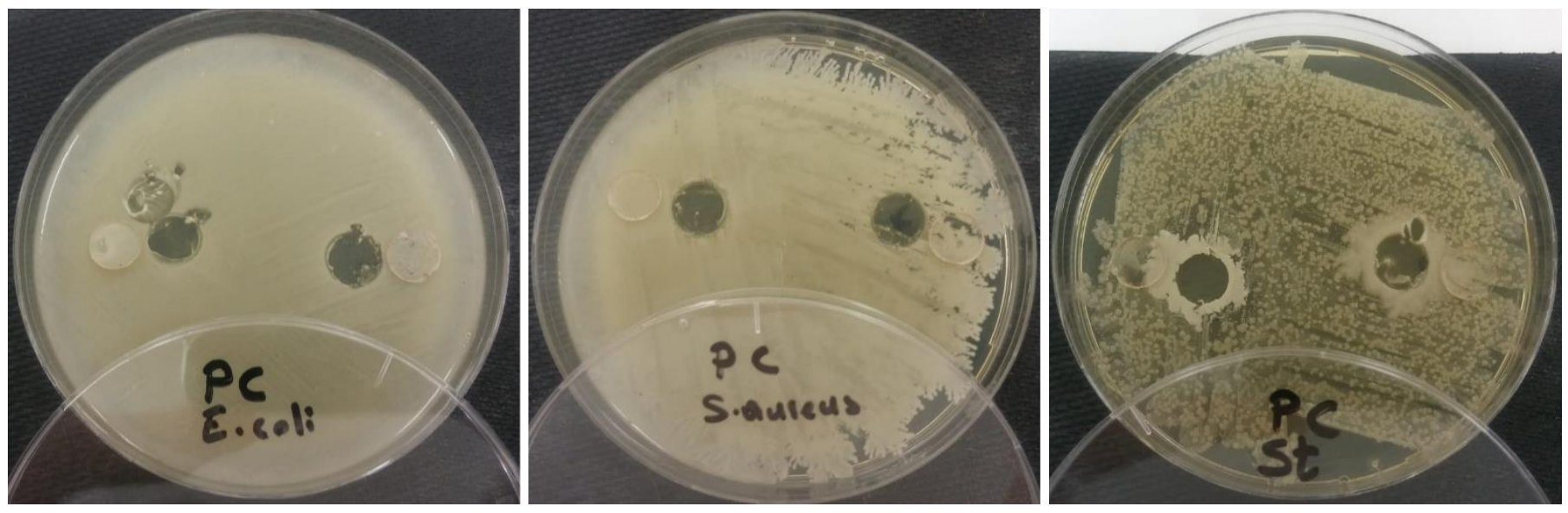

Şekil 16.PC $C^{\circledR}$ telefon korumanin antimikrobiyal özellikleri.
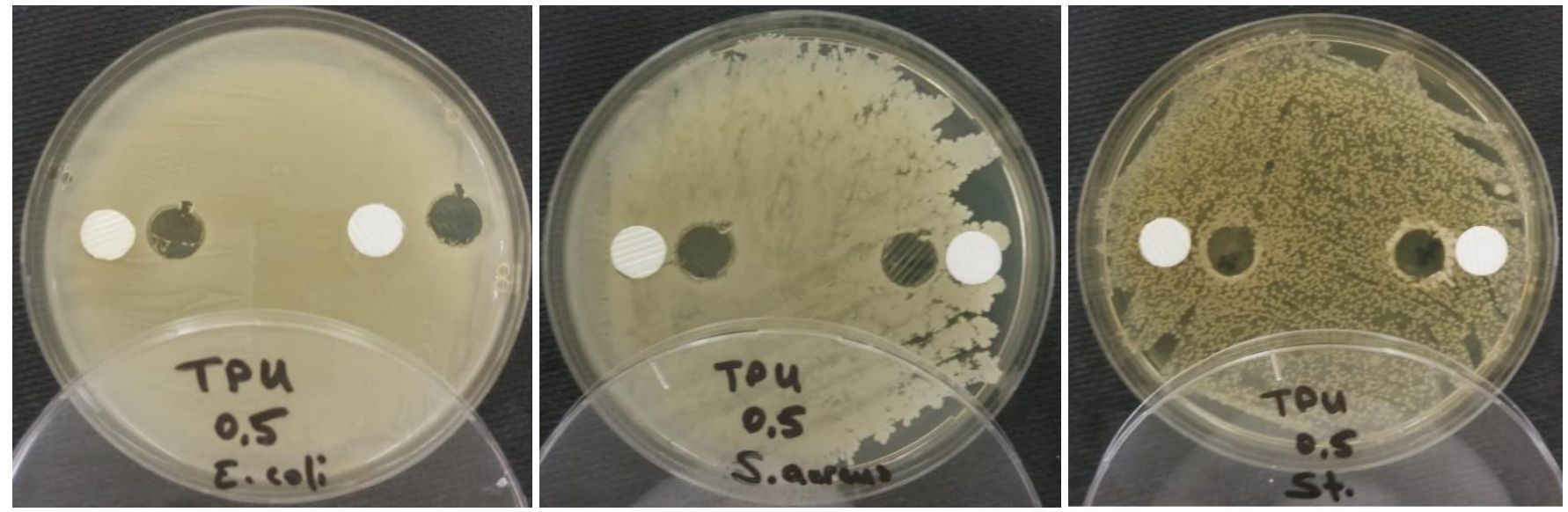

Şekil 17. TPU $U_{0,5 m m}$ telefon korumanın antimikrobiyal özellikleri.
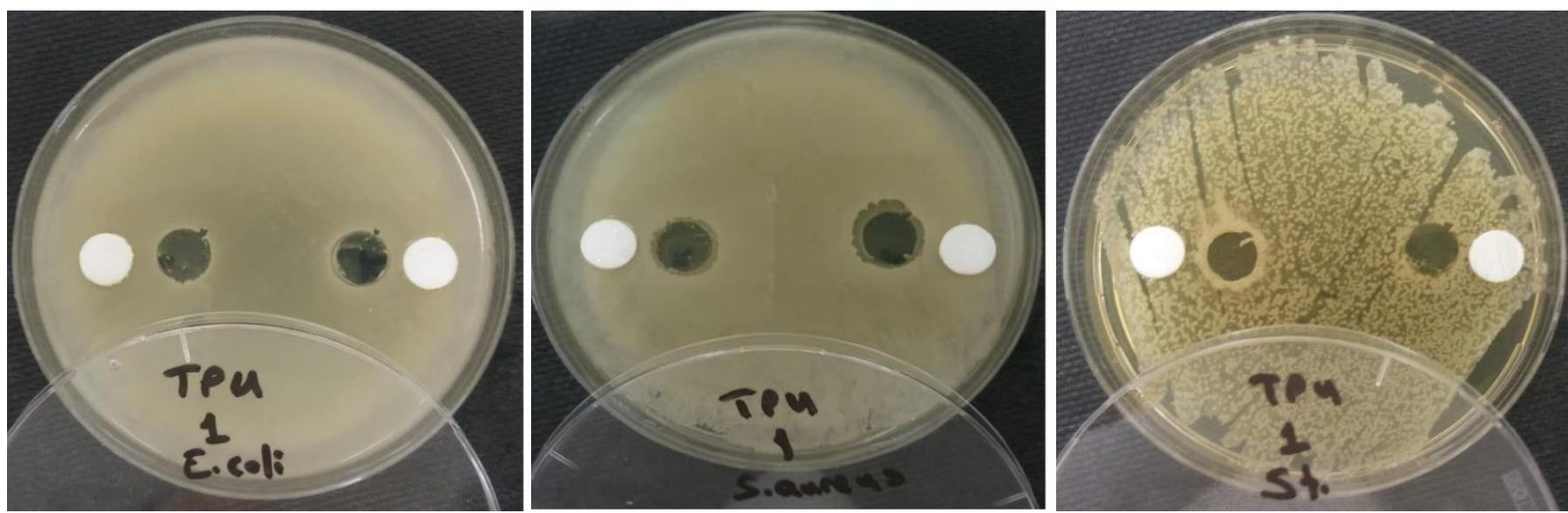

Şekil 18. TPU $U_{\text {Imm }}$ telefon korumanın antimikrobiyal özellikleri. 

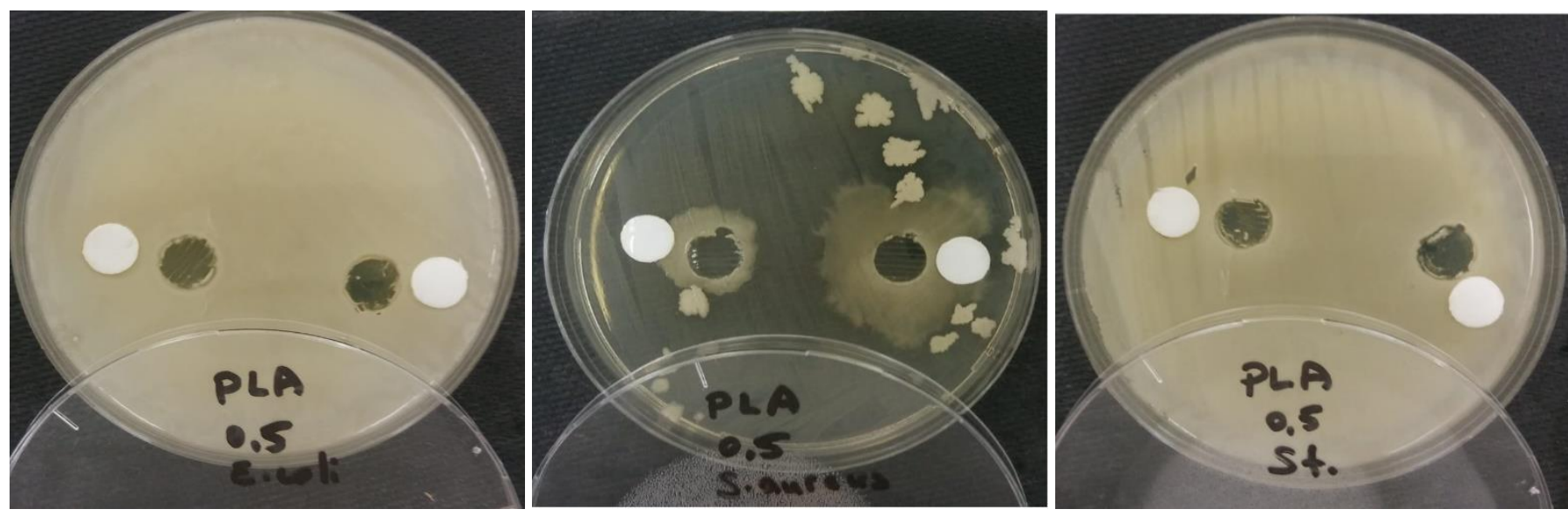

Şekil 19. PLA $A_{0,5 m m}$ telefon korumanın antimikrobiyal özellikleri.
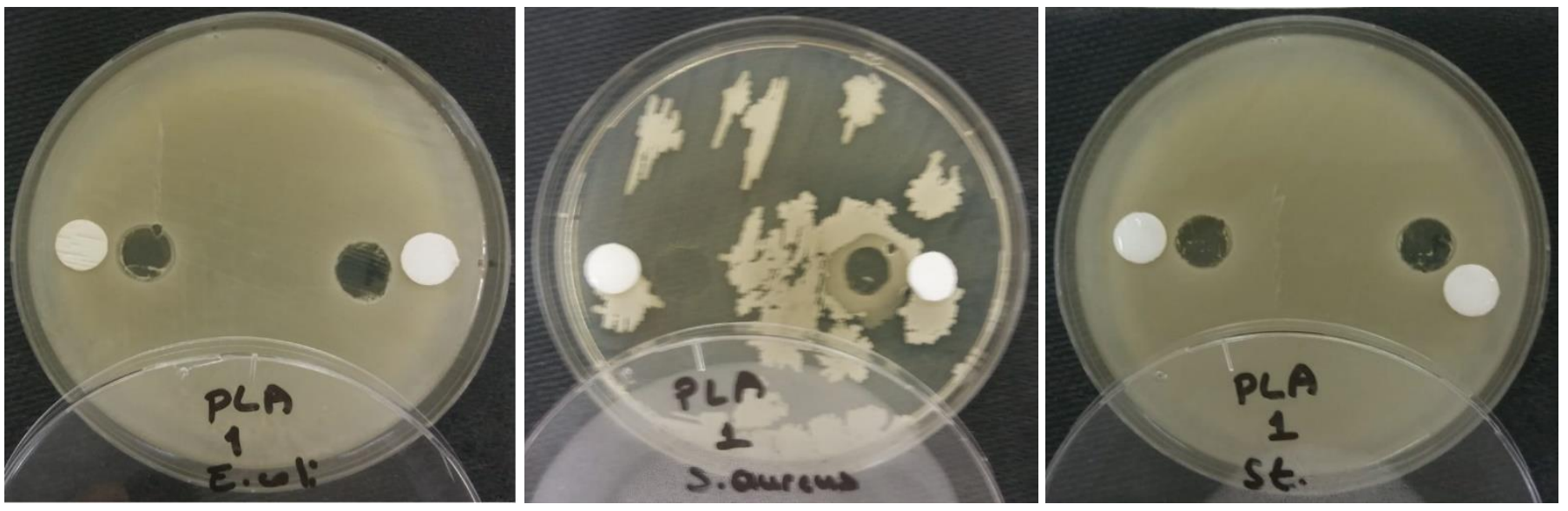

Şekil 20. PLA 1 mm telefon korumanın antimikrobiyal özellikleri.
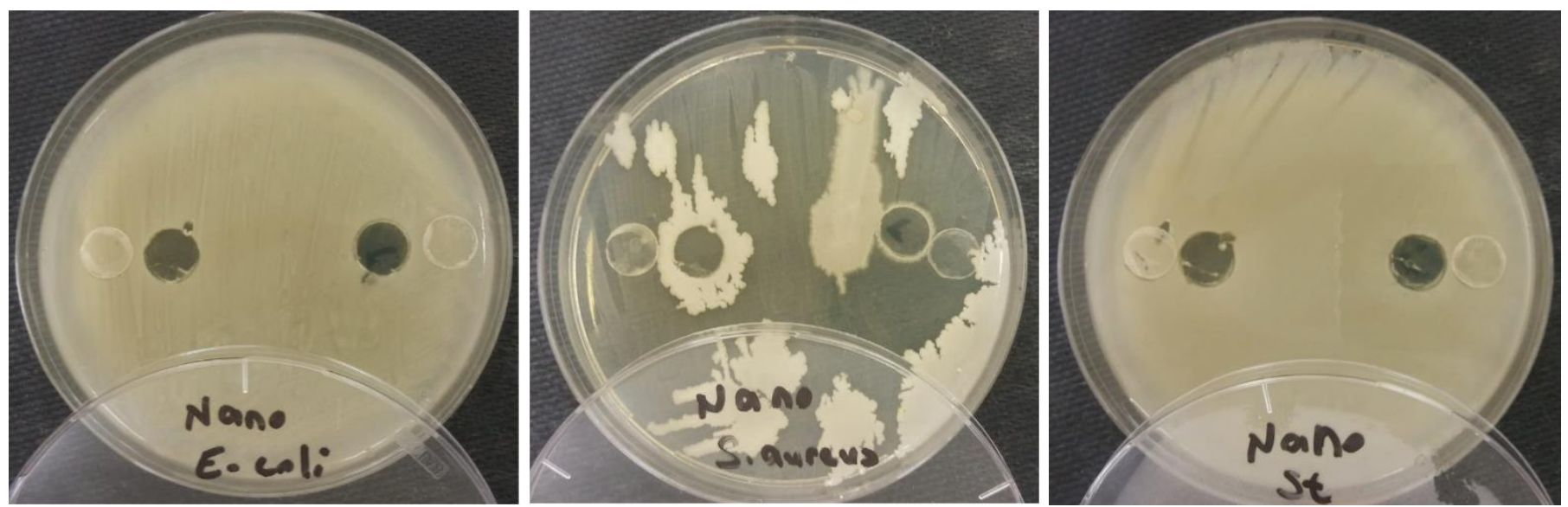

Şekil 21. Nano ${ }^{\circledR}$ ekran koruyucunun antimikrobiyal özellikleri. 

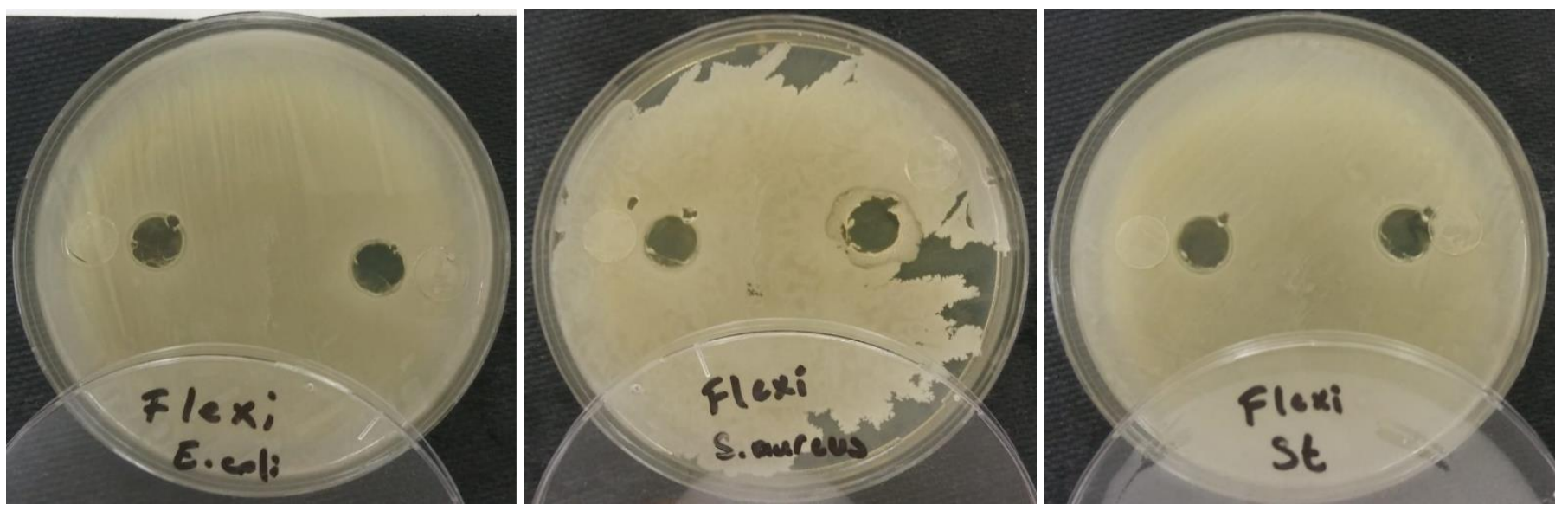

Şekil 22. Flexi ${ }^{\circledR}$ ekran koruyucunun antimikrobiyal özellikleri.

\section{Sonuç}

$\mathrm{Bu}$ çalışmada sağlık çalışanlarının tamamına yakınının akıllı telefonlarının yüzeylerinde bakteriyel üreme olduğu belirlenmiştir. Üremelerin bir kısmının ise nozokomiyal patojenlerle ilişkili olduğu saptanmıştır. Sağlık çalışanlarının telefonlarından elde edilen nozokomiyal patojenlerle plazma teknolojisi ile sağlanan telefon korumaları ve ekran koruyucuların etkileşimi değerlendirildiğinde; ticari olarak temini sağlanan TPU/silikon ${ }^{\circledR}$ içeriğe sahip telefon korumanın S.aureus ve E.coli üzerinde inhibisyon zonu oluşturarak antimikrobiyal etkinlik sağladığı tespit edilmiştir. Ancak en başarılı antimikrobiyal etkinin $13 \mathrm{~mm}$ zon oluşturarak S.pyogenes üzerinde olduğu bulunmuştur. Yine ticari olarak temini sağlanan $\mathrm{PC}^{\circledR}$, plazma teknolojisi sonrasında S.pyogenes deney örneği üzerinde neredeyse kendi çapı kadar zon oluşturmuştur. Son ticari ürün olan $\mathrm{TPU}^{\circledR} \mathrm{da}$, plazma teknolojisi sonrasında tüm mikroorganizmalar üzerinde antimikrobiyal etkinlik saptanmıştır. 3D yazıcı ile TPU ve PLA filamentden elde edilen telefon koruma örneklerinden elde edilen örneklerin antimikrobiyal etkisi ticari olarak eldesi sağlanan ürünlerden daha azdır. Bu sonucun nedeninin 3D yazıcıdan çıkan telefon korumalarının yüzeylerinin pürüzlü olmasından kaynaklandığı düşünülmektedir. Çünkü plazma teknolojisi bu yüzeyde yetersiz kalmış olabilir. Nano ${ }^{\circledR}$ e flexi ${ }^{\circledR}$ ekran koruyucularda deney ve kontrol grupları karşılaş̧ırıldığında; deney örneklerinin antimikrobiyal etki gösterdiği belirlenmiştir. Kontrol grubu örneklerinde ise disk çapı kadar üreme olduğu belirlenmiştir. Isıl olmayan teknolojiler arasinda en yeni teknolojilerden biri olarak yer alan soğuk plazma teknolojisi, günümüzde ticari olarak malzeme yüzeylerinin işlenmesi, tıbbi araçların sterilizasyonu, yara bakımı, gıda güvenliği, mikroelektronik teknolojisi, kontamine olan yüzeylerin dekontaminasyonu gibi çok farklı alanlarda etkili bir şekilde kullanılmaktadır (Driks, ve ark., 2012; Patil, ve ark., 2014; Chu, 2007). Bu çalışmada da konuyla ilgili yapılan çalışmalara benzer şekilde plazma teknolojisinin antimikrobiyal telefon koruma malzemeleri tasarımında etkin olarak kullanılabileceği sonucuna varılmıştır.

Bu çalışmadan elde edilen sonuçlara göre;

- Piyasada üretimi bulunan $\mathrm{TPU}^{\circledR}$, TPU/silikon ${ }^{\circledR}$ ve $\mathrm{PC}^{\circledR} \mathrm{ve} / \mathrm{veya}$ bunlara benzer tüm telefon koruma malzemelerine, üretim prosesi aşamasında ekstrüzyon çıkışına (yani soğuma aşamasına giriş sırasında) entegre edilecek soğuk plazma teknolojisi ile antimikrobiyal özellik e-ISSN: 2148-2683 kazandırılarak telefon korumaları ve ekran koruyucular üretilebilir.

- Antimikrobiyal özellik kazanmış bu telefon korumaları özellikle sağlık personeli gibi enfeksiyon riski taşıyan personelin kullanımına sunulabilir. Her geçen gün direnç geliştiren ve ölümlere dahi neden olan nozokomiyal enfeksiyon patojenlerinin yayılımının azaltılmasına bu şekilde katk1 sağlanabilir. Hastane ortamında bu şekilde kullanılan koruma malzemeleri küresel enfeksiyonları önlemek için mücadelede çözüm yollarından biri olabilir.

- Gelecekte üretilecek antimikrobiyal özellikli telefon korumaları sağlı personelinin kullanımına sunularak, kullanım öncesi ve sonrasi telefonlardaki bakteriyel kontaminasyon durumunu karşılaştıran çalışmalar yapılabilir. Ayrıca bu uygulamanın nozokomiyal enfeksiyon oranlarının azaltılmasında önemli boyutta etkisi olacağ1 düşünülmektedir.

\section{Kaynakça}

Alpay Y., İrvem A., Yücel M., Yavuz T. (2015). Sağlık çalışanlarının cep telefonlarında mikroorganizma kolonizasyonunun değerlendirilmesi. Balikesir Saglik Bil Derg, 4(3): 148-151. doi:10.5505/bsbd.2015.87587

Banawas, S.,Abdel-Hadi A.,. Alaidarous, M et al. (2018). Multidrug-resistant bacteria associated with cell phones of healthcare professionals in selected hospitals in SaudiArabia. Canadian Journal of Infectious Diseases and Medical Microbiology, 6598918,1-6. doi: $\underline{10.1155 / 2018 / 6598918}$

Cercenado, E.(2000). Glycopeptide-intermediate Staphylococcus aureus: rediscovery of an old problem? Clinical Microbiology and Infection, 6(10):517-518.

Chang C-H.,Chen S-Y., Lu J-J., Chang C-J.,Chang Y., Hsieh PH. (2017). Nasal colonization and bacterial contamination of mobile phones carried by medical staff in theoperatingroom. PLoS ONE 12(5), e0175811. doi:10.1371/journal. pone. 0175811 .

Chu, PK. (2007). Enhancement of surface properties of biomaterials using plasma-based technologies. Surface and Coatings Technology, 201, 8076-8082.

Colum P. Dunne, Minna M. Keinänen-Toivola, Anne Kahru, Birgit Teunissen, HulyaOlmez, et al. (2017). Antimicrobial coating innovations toprevent infectious 
diseases (AMiCI): Costaction ca15114, Bioengineered, 8(6): 679-685. doi: 10.1080/21655979.2017.1323593

Driks, BP., Dobrynin, D., Fridman, G., Mukhin, Y., Fridman, A., Quinlan JJ. (2012). Treatment of raw poultry with nonthermal dielectric barrier discharge plasma to reduce campylobacter jejuni and salmonella enterica. J. of Food Protection, 75, 22-28.

Fridman, G.,Brooks, AD., Balasubramanian, M., Fridman, A., Gutsol, A., Vasilets, VN., Ayan, H., Friedman, G. (2007). Comparison of directand indirect effects of nonthermalatmospheric-pressureplasma on bacteria. PlasmaProcessesandPolymers 4: 370-375.

Gürler, N.(2005). Hastane İnfeksiyonlarına Yol Açan Sorunlu Mikroorganizmalar Nelerdir? Sorun Oluşturma Nedenleri Nelerdir? https://www.das.org.tr/kitaplar/kitap2005/6305.pdf

Koçum, C.,Erdamar, A. Ayhan, H., (2010) Design Of Temperature Controlled Quartz Crystal Microbalance System Instrumentation Science\&Technology,38:39-51.

Koçum C., Ayhan H., (2007) Design and construction of uniform glow discharge plasma system operating under atmospheric condition, Rewiev of Scientific Instruments, 78, 063501,

Kotris, I.,. Drenjančević, D., Talapko, J., Bukovski S. (2017). Identification of microorganisms on mobile phones of intensive care unit health care workers and medical students in the tertiary hospital. Med Glas (Zenica),14(1):85-90. doi: 10.17392/878-16.

Nargiz-Koşucu S., S. Baltacı-Göktaş, T. Yıldız. (2015). Sağlık personelinin el hijyeni uyum oranı. Marmara Üniversitesi Sağlık Bilimleri Enstitüsü Dergisi, 5(2), 105-108.

Patil, ST., Moiseev, NN., Misra, PJ., Cullen, JP., Mosnier, KM., Keener, P., Bourke, M. (2014). Influence of high voltage atmospheric cold plasma process parameters and role of relative humidity on inactivation of bacillus atrophaeus spores inside a sealed package. Journal of Hospital Infection, 88, 162-169.

Rod, SK.,Hansen, F., Leipold, F., Knochel, S. (2012). Cold Atmospheric pressure plasma treatment of ready-to- eatmeat: inactivation of listeria innocua and changes in productquality. FoodMicrobiology, 30: 233-238.

T.C. Sayıştay Başkanlığı, Hastane Enfeksiyonları İle Mücadele Performans Denetimi Raporu, ARALIK-2007. İnternet erişim: http://www.hider.org.tr/Yeniden/20072hastaneenfeksiyon.Pdf

Ulger, F., Dilek, A., Esen, S., Sunbul, M., Leblebicioglu, H. (2015). Arehealthcareworkers' mobile phones a potentialsource of nosocomial infections, Review of theliterature. J Infect Dev Ctries, 9(10):1046-1053. doi:10.3855/jidc.6104

Ulger, F., Esen, S., Dilek A., Yanik K., Gunaydin M., Leblebicioglu H..(2009) Areweaware how contaminatedour mobile phones with nosocomial pathogens? Annals of Clinical Microbiology and Antimicrobials, 8:7 doi:10.1186/1476-0711-8-7

Wayne PA.(2011). Clinical and Laboratory Standards Institute. Performance Standarts for Antimicrobial Susceptibility Testing, 21th Informational Supplement, CLSI/ NCCLS Document M100-S21: CLSI.

Yangilar, F., Oğuzhan, P. (2013). Plazma Teknolojilerinin Gıda Endüstrisinde Kullanımı. Gıda, 38(3): 183-189.
Yasuda, H. (1984). Plasmapolymerization for protective coatings and composite membranes. Journal of Membrane Science, 18: 273-284.

Zakai, S., Mashat, A., Abumohssin, A., Samarkandi A., Almaghrabi B., Barradah H., Jiman-Fatani A. (2016). Bacterialcontamination of cellphones of medicalstudents at KingAbdulazizUniversity, Jeddah, SaudiArabia. J Microsc Ultrastruct, 4 (3), 143-146. doi: 10.1016/j.jmau..12.004. 